\author{
Marquette University \\ e-Publications@Marquette
}

Civil and Environmental Engineering Faculty Research and Publications

Civil, Construction, and Environmental Engineering, Department of

$9-1-2019$

\title{
Sequential Electrocoagulation-Electrooxidation For Virus Mitigation in Drinking Water
}

Joe Heffron

Marquette University

Donald R. Ryan

Marquette University

Brooke K. Mayer

Marquette University, Brooke.Mayer@marquette.edu

Follow this and additional works at: https://epublications.marquette.edu/civengin_fac

Part of the Civil Engineering Commons

\section{Recommended Citation}

Heffron, Joe; Ryan, Donald R.; and Mayer, Brooke K., "Sequential Electrocoagulation-Electrooxidation For Virus Mitigation in Drinking Water" (2019). Civil and Environmental Engineering Faculty Research and Publications. 235.

https://epublications.marquette.edu/civengin_fac/235 
Marquette University

\section{e-Publications@Marquette}

\section{Civil, Construction and Environmental Engineering Faculty Research and Publications/College of Engineering}

This paper is NOT THE PUBLISHED VERSION; but the author's final, peer-reviewed manuscript.

The published version may be accessed by following the link in the citation below.

Water Research, Vol. 160 (September 1, 2019): 435-444. DOI. This article is (C) Elsevier and permission has been granted for this version to appear in e-Publications@Marquette. Elsevier does not grant permission for this article to be further copied/distributed or hosted elsewhere without the express permission from Elsevier.

\section{Sequential Electrocoagulation- Electrooxidation For Virus Mitigation in Drinking Water}

Joe Heffron

Department of Civil, Construction and Environmental Engineering, Marquette University, Milwaukee, WI Donald R. Ryan

Department of Civil, Construction and Environmental Engineering, Marquette University, Milwaukee, WI Brooke K. Mayer

Department of Civil, Construction and Environmental Engineering, Marquette University, Milwaukee, WI

Highlights

- Ferrous iron impaired, rather than enhanced, electrooxidation for virus treatment.

- Sequential electrocoagulation-electrooxidation was beneficial for surface waters. 
- Electrocoagulation alone was preferable for groundwaters.

- Bacteriophages MS2 and $\Phi$ X174 overestimated virus reduction compared to echovirus.

\section{Abstract}

Electrochemical water treatment is a promising alternative for small-scale and remote water systems that lack operational capacity or convenient access to reagents for chemical coagulation and disinfection. In this study, the mitigation of viruses was investigated using electrocoagulation as a pretreatment prior to electrooxidation treatment using boron-doped diamond electrodes. This research is the first to investigate a sequential electrocoagulation-electrooxidation treatment system for virus removal. Bench-scale, batch reactors were used to evaluate mitigation of viruses in variable water quality via: a) electrooxidation, and b) a sequential electrocoagulation-electrooxidation treatment train. Electrooxidation of two bacteriophages, MS2 and $\Phi \times 174$, was inhibited by natural organic matter and turbidity, indicating the probable need for pretreatment. However, the electrocoagulationelectrooxidation treatment train was beneficial only in the model surface waters employed. In model groundwaters, electrocoagulation alone was as good or better than the combined electrocoagulationelectrooxidation treatment train. Reduction of human echovirus was significantly lower than one or both bacteriophages in all model waters, though bacteriophage $\Phi$ X174 was a more representative surrogate than MS2 in the presence of natural organic matter and turbidity. Compared to conventional treatment by ferric salt coagulant and free chlorine disinfection, the electrocoagulation-electrooxidation system was less effective in model surface waters but more effective in model groundwaters. Sequential electrocoagulation-electrooxidation was beneficial for some applications, though practical considerations may currently outweigh the benefits.

\section{Graphical abstract}

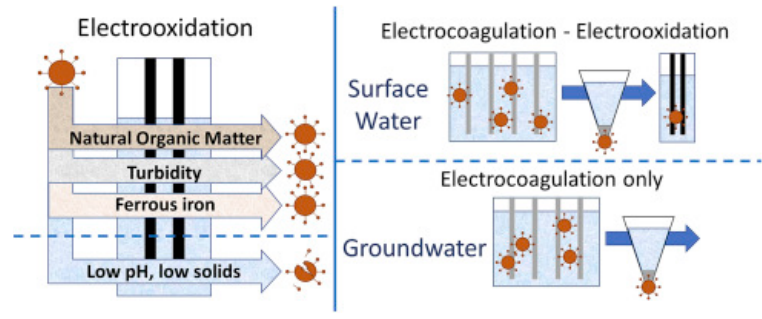

\section{Keywords}

Bacteriophage, Electrochemical, Disinfection, Echovirus, Inactivation, Iron

\section{Introduction}

Electrochemical water treatment holds promise as a portable option for coagulation and disinfection in small-scale water systems. More than half of the public water systems in the United States (US) serve fewer than 500 people (EDR Group, 2013), and approximately 15\% of individuals in the US get water from private wells (DeSimone, 2009). Many of these public and private water systems draw from groundwater and lack disinfection treatment processes. Between 1971 and 2014, over half of the drinking water outbreaks in the US were due to untreated or inadequately treated groundwater (Centers for Disease Control and Prevention, 2017; Craun et al., 2010). 
Electrooxidation (EO) uses inert electrodes to directly oxidize contaminants at the electrode surface and/or generate oxidants in solution. Boron-doped diamond (BDD) electrodes are commonly used in EO research due to BDD's high resistance to chemical and thermal degradation and low tendency to react with solvents (Macpherson, 2015; Radjenovic and Sedlak, 2015). BDD EO is capable of disinfecting pathogens through either the production of reactive oxygen species (ROS) from electrochemical water decomposition or free chlorine and chlorine dioxide produced from oxidation of chloride ( $\mathrm{He}$ et al., 2019; Palmas et al., 2007; Polcaro et al., 2009; Rajab et al., 2015). In the absence of chloride, hydroxyl radicals at the electrode surface are the primary oxidant species, and disinfection relies on pathogen transport and sorption to the electrode surface (Bruguera-Casamada et al., 2017; Jeong et al., 2006). In general, the efficacy of BDD disinfection increases with the concentration of chloride in the water matrix (Lacasa et al., 2013; Mascia et al., 2013; Polcaro et al., 2009; Rajab et al., 2015). Increased disinfection in the presence of chloride may indicate that chlorine species are more important to BDD disinfection compared to ROS. Alternatively, chlorine may have a synergistic effect on ROS generation, with more ROS generated in high chloride matrices (Rajab et al., 2015).

A combined process using EO with BDD followed by electrocoagulation (EC) was used by Cotillas et al. (2013) and Llanos et al. (2014) for E. coli mitigation. EC is the in situ formation of coagulant in water due to oxidation of a sacrificial anode, typically aluminum or iron. EC has been considered as a pretreatment process for removal of turbidity and natural organic matter (NOM) in a variety of applications (Bagga et al., 2008; Ben-Sasson et al., 2011; Dubrawski et al., 2013; Vepsäläinen et al., 2009). EC is also an effective means of virus reduction (Heffron and Mayer, 2016). The primary mechanism of EC is often considered to be the same as chemical coagulation, i.e., physical removal by charge neutralization or sweep flocculation (Heffron and Mayer, 2016). However, EC can also inactivate viruses and bacteria via generation of free chlorine or Fenton-like reactive intermediates due to ferrous iron oxidation (Delaire et al., 2015; Heffron et al., 2019a, 2019b; Kim et al., 2011; Tanneru et al., 2014; Zhu et al., 2005). Iron EC generates ferrous ions $\left(\mathrm{Fe}^{2+}\right)$ in solution by oxidizing a zero-valent iron electrode (Lakshmanan and Clifford, 2009; Li et al., 2012). The oxidation of ferrous ions to ferric can generate intermediate oxidants

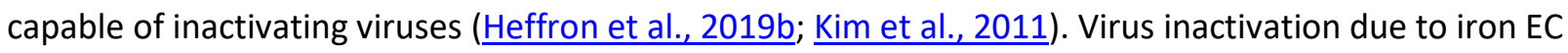
is more prevalent in slightly acidic waters $(\sim \mathrm{pH} 6)$, while physical removal is the dominant fate of viruses in iron EC above pH 7 (Heffron et al., 2019a). In a combined EO-EC reactor, Llanos et al. (2014) found that iron electrodes were more effective for $E$. coli reduction compared to aluminum electrodes. The team attributed the greater removal observed with iron electrodes to the formation of a passivation layer on aluminum electrodes, though the possibility of $E$. coli inactivation due to iron oxidation was not investigated.

Disinfection by means of EO has been extensively investigated for mitigation of bacteria (Ahmadi and Wu, 2017; Bruguera-Casamada et al., 2017, 2016; Cossali et al., 2016; Cotillas et al., 2013; Hussain et al., 2014; Lacasa et al., 2013; Rajab et al., 2015), but virus mitigation by EO has received comparatively little attention (Drees et al., 2003; Fang et al., 2006; Huang et al., 2016). Both bacteriophage MS2 and recombinant human adenovirus have been found to be more resistant to electrochemical disinfection

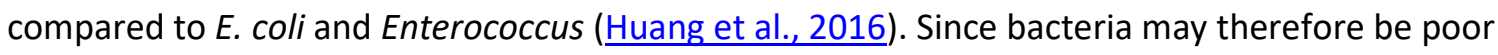
indicators of virus disinfection via EO, the lack of information on virus mitigation by EO is a critical gap in the literature. Moreover, EC pretreatment ahead of EO may offer advantages for virus treatment, but has not yet been thoroughly assessed. 
The goal of this study was to evaluate iron EC as a pretreatment for disinfection of waterborne viruses via BDD EO. To accomplish this goal, the effects of $\mathrm{pH}$, natural organic matter, and turbidity on virus mitigation by EO were first evaluated. The impact of ferrous iron on EO was also investigated in order to design an effective treatment train using sequential EC and EO. Next, a sequential EC-EO treatment train was evaluated for mitigation of two bacteriophage surrogates and echovirus in four synthetic water matrices representing a range of source waters. The EC-EO system was then compared to a more conventional treatment train comprising chemical coagulation and free chlorine disinfection.

Notably, in testing water treatment processes, bacteriophage surrogates are frequently used in place of human viruses for reasons of cost, ease, and safety (Amarasiri et al., 2017; Boudaud et al., 2012; Ferrer et al., 2013; Grabow, 2001). However, surrogates should be compared to human viruses of interest in any novel application. Echovirus is a ubiquitous pathogen in human-impacted water systems and among the smallest viruses, with diameters typically smaller than $30 \mathrm{~nm}$ (Grabow, 2007; World Health Organization, 1996). Previous research (Heffron et al., 2019a) has determined that echovirus 12 is resistant to inactivation by EC and is therefore a conservative indicator of virus mitigation.

\section{Materials and methods}

\subsection{Batch electrocoagulation and electrooxidation process operation}

All EC and EO tests were conducted in 200-mL polypropylene batch reactors. EC reactors utilized four 1020 steel electrodes (VMetals, Milwaukee, WI). EO reactors used a single BDD/Si anode (NeoCoat SA, La Chaux-de-Fonds, France) and commercially available pure Grade 2 titanium as an inert cathode (Performance Titanium Group, San Diego CA). Similar disinfection performance may be possible with lower cost electrodes, for example graphite (Hussain et al., 2014; Saha and Gupta, 2017). However, BDD electrodes were used in this study as a representative EO treatment because of the prevalence of BDD usage in electrochemical disinfection research. The BDD coating was $3 \mu \mathrm{m}$ thick and p-doped with 700$800 \mathrm{ppm}$ boron. All electrodes had a submerged working surface area of $15 \mathrm{~cm}^{2}(5 \mathrm{~cm} \times 3 \mathrm{~cm})$.

Prior to use, iron EC electrodes were wet-polished with 400 grit Si-C sandpaper, triple-rinsed with PureLab ultrapure water (ELGA LabWater, UK), and then disinfected under UV light for 30 min per side in a biosafety cabinet. EC electrodes were polarized at $100 \mathrm{~mA}$ in $3 \mathrm{mM}$ sodium bicarbonate solution for $10 \mathrm{~min}$ to mimic conditions of continual use in drinking water, then thoroughly rinsed with ultrapure water to remove residual iron. The BDD anode and titanium cathode were polarized at $100 \mathrm{~mA}$ for $10 \mathrm{~min}$ in $0.1 \mathrm{M} \mathrm{H}_{2} \mathrm{SO}_{4}$ to rehydrogenize the electrode surface before each test in order to provide consistent electrode conditions (Jeong et al., 2006; Macpherson, 2015).

\subsection{Virus propagation and quantification}

Two bacteriophages were used as human virus surrogates: MS2 (ATCC \#15597-B1) and DX174 (ATCC \#13706-B1). MS2 is an F-specific coliphage with a single-stranded RNA genome (Baltimore group IV), while ФX174 is a somatic coliphage with a single-stranded DNA genome (Baltimore group II) (Grabow, 2001). These bacteriophages are standard laboratory surrogates for enteric viruses (Heffron and Mayer, 2016). To evaluate the suitability of these bacteriophage surrogates for indicating human virus mitigation during electrochemical treatment, human echovirus 12 (ATCC \#VR-1563) was used to verify a subset of tests. 
Bacteriophages were propagated using the double-agar layer (DAL) method. E. coli ATCC \#15597 and \#13706 were used to propagate and quantify MS2 and $\Phi \times 174$, respectively. Echovirus was propagated in Buffalo Green Monkey Kidney cell culture (ATCC CCL-161) until cell monolayers were reduced to approximately $10-20 \%$ confluence, then subjected to three freeze-thaw cycles at $-20^{\circ} \mathrm{C}$. All viruses were purified by two cycles of polyethylene glycol (PEG) precipitation followed by a Vertrel XF (DuPont, Wilmington, DE) purification, as described by Mayer et al. (2008). Bacteriophages were quantified using the spot titer plaque assay method, as described by Beck et al. (2009). Echovirus was quantified using the Reed \& Muench TCID 50 method (Reed and Muench, 1938). Bacteriophages were stored at $4{ }^{\circ} \mathrm{C}$. Even at low concentrations, dimethyl sulfoxide (DMSO) inhibited bacteriophage inactivation due to EO, as shown in the Supporting Information (SI) 1 . DMSO exerts a high demand for hydroxyl radicals at concentrations as low as $0.25 \mathrm{mM}$ (Tai et al., 2004). For this reason, echovirus was stored at $-20^{\circ} \mathrm{C}$ without cryopreservant and was used within 2 months of propagation.

Bacteriophages were spiked at concentrations of approximately $10^{7} \mathrm{PFU} / \mathrm{mL}$, while echovirus was spiked at approximately $10^{4} \mathrm{TCID}_{50} / \mathrm{mL}$ due to limitations in virus propagation. After treatment, the reactor was briefly homogenized by rapid stirring ( $600 \mathrm{rpm}$ for $15 \mathrm{~s}$ ), and a $20-\mathrm{mL}$ sample was taken for virus elution. Elution was performed 15 min after EO treatment to allow the same reaction time as EC. Elution was performed by adding an equal volume of $6 \%$ beef broth to homogenized samples and vortexing for approximately $10 \mathrm{~s}$. Samples containing bacteriophages were diluted in tenfold series in $\mathrm{pH} 7.0$ buffered demand free (BDF) water, and ten $10-\mu \mathrm{L}$ drops of each dilution were plated. Samples containing echovirus were also diluted in BDF. Aliquots of $100 \mu \mathrm{L}$ from each echovirus dilution series were added to 6 wells in a 24-well tray of 1-day-old BGM cells. BGM cultures were observed under magnification for the appearance of cytopathic effects over the following 10 days, and were quantified using the Reed \& Muench TCID $_{50}$ method (Reed and Muench, 1938).

\subsection{Impact of water constituents on electrooxidation}

To test the impact of NOM, turbidity, $\mathrm{pH}$, and ferrous iron on EO with BDD electrodes, batch EO tests were performed at a constant current of $20 \mathrm{~mA}\left(i=1.3 \mathrm{~mA} / \mathrm{cm}^{2}\right)$ for $5 \mathrm{~min}$. Sodium bicarbonate (2.1 $\mathrm{mM}$ ) was added to ultrapure water for a background electrolyte solution, and $\mathrm{pH}$ was adjusted with $1 \mathrm{M} \mathrm{H}_{2} \mathrm{SO}_{4}$ or $\mathrm{NaOH}$. NOM, turbidity, and ferrous iron tests were conducted at $\mathrm{pH} 7$; $\mathrm{pH}$ tests were conducted at $\mathrm{pH} \mathrm{6,7,} \mathrm{and} \mathrm{8.} \mathrm{NOM} \mathrm{was} \mathrm{added} \mathrm{as} \mathrm{humic} \mathrm{acid} \mathrm{sodium} \mathrm{salt} \mathrm{(Sigma} \mathrm{Aldrich,} \mathrm{St.} \mathrm{Louis,} \mathrm{MO)} \mathrm{at}$ concentrations of $0.1-15 \mathrm{mg} / \mathrm{L}$ total organic carbon (TOC). Turbidity was increased by adding $\mathrm{A} 2$ test dust (Powder Technology Inc., Arden Hills, MN) to approximately 1-30 NTU. Contributions of NOM to TOC were measured using a TOC-V CSN total organic carbon analyser (Shimadzu, Kyoto, Japan) following sample acidification with analytical grade hydrochloric acid. Though NOM contributes to turbidity, tests were performed by adding enough A2 dust to provide the target turbidity (see SI 2) independent of NOM. Turbidity was measured using a Hach 2100AN Turbidimeter (Hach, Loveland, CO).

\subsection{Sequential electrocoagulation-electrooxidation process operation}

A treatment train schematic for sequential EC-EO treatment is shown in Fig. 1. Preliminary testing determined that a particle separation step between the EC and EO stages provided greater bacteriophage reduction, as shown in $\mathrm{SI} 3$. For this reason, the entire volume of the reactor was filtered before EO treatment with a Whatman 114 filter to remove coarse precipitates ( $>25 \mu \mathrm{m}$ ) without affecting turbidity or NOM. Due to potential formation of iron flocs from dissolved iron during EO treatment, an additional filtration step was performed after EO as well. After final filtration, 5-mL 
samples were diluted into $5 \mathrm{~mL} 6 \%$ beef broth ( $\mathrm{pH} 9.5$ ) to elute viruses from any remaining floc and promote monodispersion.

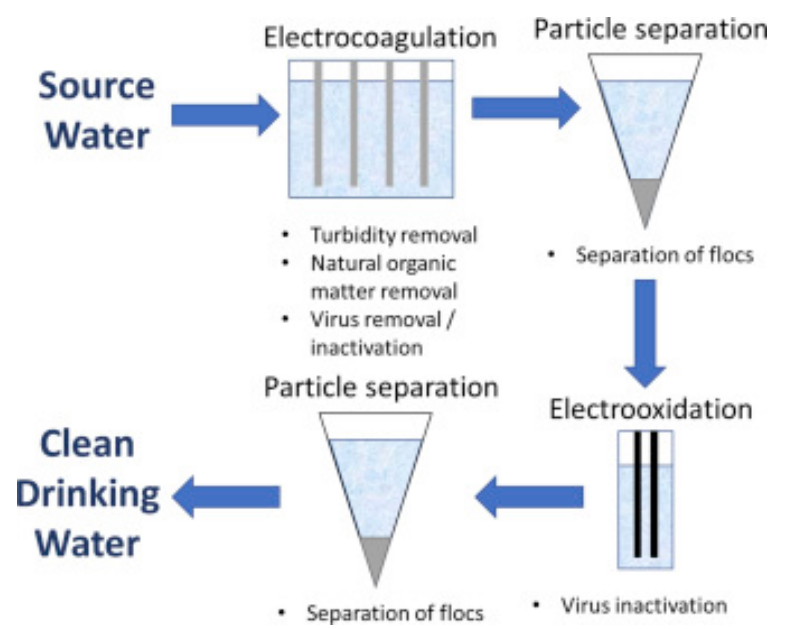

Fig. 1. Schematic of electrocoagulation-electrooxidation treatment train and hypothesized treatment effects for each stage.

Untreated controls were performed along with every EC-EO treatment test. All untreated controls were retained in reactors for the same amount of time as treated replicates (but without electrochemical treatment) and underwent the same filtration and elution procedures. Log reduction of viruses was calculated by comparing eluted virus concentrations after EC-EO to these untreated controls. Therefore, these controls accounted for any minor losses of virus due to sorption to the coarse filters or elution. The data indicated that virus concentrations remained at approximately the spiked concentration in the untreated controls ( $10^{7} \mathrm{PFU} / \mathrm{mL}$ for bacteriophages and $10^{4} \mathrm{TCI}_{50} / \mathrm{mL}$ for echovirus), indicating that any virus loss due to experimental artifact was minor. In combination with floc formation, some fraction of viruses was expected to be retained with the floc on the coarse filter. In any coagulation process, some method of floc separation is required, whether settling, centrifugation or filtration. In this case, a coarse filter was used for expediency compared to gravitational separation and to provide a more conservative account of physical separation compared to microfiltration.

A constant charge loading of $150 \mathrm{C} / \mathrm{L}$ was divided between the $\mathrm{EC}$ and $\mathrm{EO}$ processes by varying current over a constant retention time of 5 min per treatment process. The charge loading of $150 \mathrm{C} / \mathrm{L}(50 \mathrm{~mA}$ applied over $10 \mathrm{~min}$ total reaction time in a $200 \mathrm{~mL}$ reactor, $i_{\mathrm{EC}}=1.1 \mathrm{~mA} / \mathrm{cm}^{2}, i_{\mathrm{EO}}=3.3 \mathrm{~mA} / \mathrm{cm}^{2}$ ) was chosen in order to establish a curve that demonstrated differences between charge allocations and virus log reduction without exceeding the measurable limit of virus reduction ( 5 log reduction), as explained in SI 4. Total and ferrous iron concentrations were measured using Hach FerroVer Total Iron and Ferrous Iron Reagent (Hach, Loveland, CO). Absorbance was measured at $510 \mathrm{~nm}$ using a Genesys 20 spectrophotometer (Thermo Fisher Scientific, Waltham, MA).

\subsection{Preparation of synthetic waters for sequential EC-EO process}

Removal of the two bacteriophage surrogates (MS2 and $\Phi \times 174$ ) and echovirus was evaluated in synthetic waters modeled after a range of environmental source waters. Four model waters were synthesized by adding reagent-grade chemicals to ultrapure water and adjusting $\mathrm{pH}, \mathrm{NOM}$, and turbidity, as shown in Table 1. Model water parameters were based on water quality data for the Mississippi River at Brooklyn Park, MN, Lake Michigan at Milwaukee, WI, and shallow (dolomite), and 
deep (sandstone) aquifers near Lincoln township and Waukesha, WI, as detailed in SI 2. To represent the anoxic conditions of groundwater, Dolomite and Sandstone Aquifer model waters were degassed using argon for $15 \mathrm{~min}$ prior to $\mathrm{pH}$ adjustment and virus addition.

Table 1. Model water parameters.

\begin{tabular}{|l|l|l|l|l|l|l|l|}
\hline Water Matrix & $\begin{array}{l}\text { Alkalinity } \\
(\mathrm{mg} / \mathrm{L} \text { as } \\
\left.\mathrm{CaCO}_{3}\right)\end{array}$ & $\begin{array}{l}\text { Chloride } \\
(\mathrm{mg} / \mathrm{L})\end{array}$ & $\begin{array}{l}\text { Added } \\
\text { Turbidity } \\
(\mathrm{NTU})\end{array}$ & $\begin{array}{l}\text { Total Organic } \\
\text { Carbon } \\
(\mathrm{mg} / \mathrm{L})\end{array}$ & $\mathrm{pH}$ & $\begin{array}{l}\text { Conductivity } \\
(\mu \mathrm{S} / \mathrm{cm})\end{array}$ & $\begin{array}{l}\text { Dissolved } \\
\text { Oxygen } \\
(\mathrm{mg} / \mathrm{L})\end{array}$ \\
\hline Lake Michigan & 118 & 13 & 0 & 2 & 8.3 & 340 & 9 \\
\hline $\begin{array}{l}\text { Mississippi } \\
\text { River }\end{array}$ & 162 & 11 & 30 & 8.7 & 8.1 & 400 & 9 \\
\hline $\begin{array}{l}\text { Sandstone } \\
\text { (deep) Aquifer }\end{array}$ & 220 & 4 & 0 & 0 & 7.5 & 550 & 0.3 \\
\hline $\begin{array}{l}\text { Dolomite } \\
\text { (shallow) } \\
\text { Aquifer }\end{array}$ & 320 & 70 & 10 & 0 & 7.5 & 1000 & 0.4 \\
\hline
\end{tabular}

\subsection{Comparison of sequential EC-EO to conventional coagulation/disinfection}

Ferric chloride was added to match the iron dose achieved by $50 \mathrm{~mA} \mathrm{EC}$ with a 5 -min retention time (22 mg Fe/L) to represent a 50/50 allocation of charge for EC-EO. Reactors were rapidly stirred (600 rpm) for $30 \mathrm{~s}$, followed by a slower stir rate $(200 \mathrm{rpm}$, as used in EC) for $270 \mathrm{~s}$ (total reaction time of $5 \mathrm{~min}$ ). Consistent with EC-EO treatment tests, reactors were allowed to settle for $15 \mathrm{~min}$ without stirring, and then the total volume was passed through a Whatman 114 filter. Sodium hypochlorite was added ( $1.2 \mathrm{mg} / \mathrm{L}$ as $\mathrm{Cl}_{2}, 5 \mathrm{~min}$ retention) to meet the recommended $6 \mathrm{mg}$-min/L chlorine dose for small water treatment systems (Washington Administrative Code, 2017). After 5 min retention time, an excess of sodium thiosulfate $(0.03 \mathrm{mM})$ was added to the reactor to quench residual chlorine.

\subsection{Data analysis}

All statistical analyses were performed in the R statistical language using the stats package ( $\mathrm{R}$ Core Team, 2014). Bacteriophage inactivation was correlated to charge allocation between EC and EO by linear regression. Models were evaluated for residual distribution, normality, and leverage points (Cook's distance) using the plot.Im() function, and significance of variables was evaluated by analysis of variance with the anova() function (R Core Team, 2014). Akaike's 'An Information Criterion' was used to evaluate the goodness-of-fit and parsimony of competing linear models ( $\underline{R}$ Core Team, 2014; Sakamoto et al., 1986).

Echovirus tests were performed in triplicate at 0,50, and 100\% charge allocations to EC and compared to MS2 and $\Phi \times 174$ reduction in the same waters at all charge allocations. One-way ANOVA was performed to assess differences in mean removal between viruses within each model water. Post-hoc comparison of means was performed using Tukey's HSD using the aov() and TukeyHSD() functions ( Core Team, 2014).

The electrical energy per order of magnitude (EEO, Bolton et al., 1996) virus reduction was calculated for the sequential EC-EO treatment in the four model waters. This parameter provides a benchmark for comparing the energy costs of virus mitigation in different treatment scenarios. 


\section{Results and discussion}

\subsection{Effect of water constituents on BDD electrooxidation}

To evaluate the impact of water quality on virus inactivation via EO, BDD EO was performed under conditions of varying NOM, turbidity, and pH. Both NOM and turbidity impeded EO, as shown in Fig. 2. NOM increases oxidant demand, resulting in poorer disinfection of target pathogens (Haselow et al., 2003). NOM is particularly effective at quenching hydroxyl radicals, with a rate constant near $10^{8} \mathrm{M}^{-1} \mathrm{~s}^{-1}$ (Westerhoff et al., 2007). Hydrophobic virions may also sorb to, and be shielded by, NOM. The $A 2$ test dust used to increase turbidity consists of silica, alumina, and various metal oxides (Powder Technology Inc., 2016). The presence of metal oxides in A2 test dust likely provides oxidant demand, leading to the poor inactivation shown in Fig. 2B. Therefore, a pretreatment stage prior to EO is needed to mitigate the negative influence of NOM and turbidity on virus inactivation during EO.
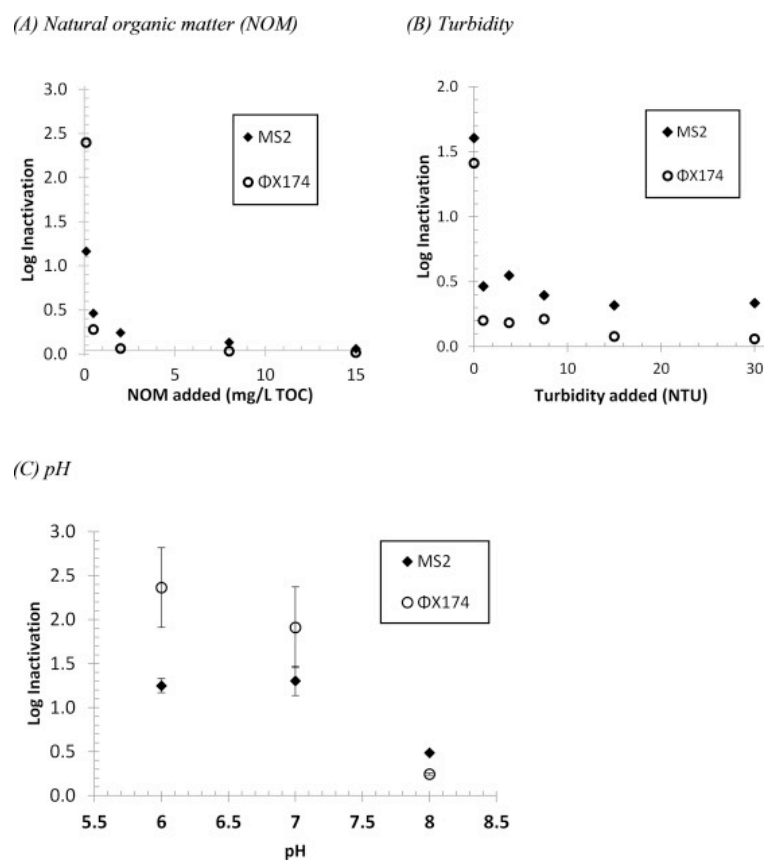

Fig. 2. Impact of water quality, (A) natural organic matter, (B) turbidity, and (C) pH, on bacteriophage MS2 and $\Phi \times 174$ reduction by electrooxidation using boron-doped diamond (BDD) electrodes (20 mA, $5 \mathrm{~min}$ ). Tests were conducted in $2.1 \mathrm{mM} \mathrm{NaHCO}_{3}$. Both NOM and turbidity inhibited inactivation, and inactivation was significantly lower at $\mathrm{pH}$ 8. Points in Fig. 2A and B represent single tests (mean of 10 counts). In Fig. $2 \mathrm{C}$, points represent mean values of triplicate tests with \pm 1 standard error shown by the error bars.

Reduction of both MS2 and $\Phi \times 174$ was greater at $\mathrm{pH} 6$ and 7 compared to $\mathrm{pH} 8$, as shown in Fig. 2C. Generation of ROS (primarily hydroxyl radicals) due to EO is greater at lower pH (Jeong et al., 2006). Inactivation of either bacteriophage was not statistically different between triplicate tests at $\mathrm{pH} 6$ and 7 . Therefore, virus reduction above $\mathrm{pH} 7$ should be a conservative indicator of reduction in slightly acidic waters as well. For this reason, model waters below $\mathrm{pH} 7$ were not investigated in later experiments. In all tests, $\mathrm{pH}$ increased slightly during the EO process by an average of $0.20 \pm 0.05 \mathrm{pH}$ units. 


\subsection{Impact of ferrous iron on BDD electrooxidation}

In addition to directly oxidizing contaminants, ferrous iron can enhance other oxidation treatment processes. Iron-enhanced oxidation has been demonstrated for many contaminants. Ferrous-catalyzed ozonation has been found to be more effective than ozonation alone in oxidizing organic pollutants and COD (Arslan-Alaton, 2001; Beltrán et al., 2005; Legube and Karpel Vel Leitner, 1999). Researchers have found that ferric iron has similar, albeit possibly lesser, catalytic effects for ozonation of organic pollutants (Beltrán et al., 2005; Sreethawong and Chavadej, 2008). Though disinfection studies using iron-enhanced oxidation are scarce, Sjogren and Sierka (1994) found that $2 \mu \mathrm{M}$ ferrous sulfateaugmented $\mathrm{TiO}_{2}$ photocatalysis achieved an additional $2 \log _{10}$ reduction of $\mathrm{MS}_{2}$ over $\mathrm{TiO}_{2}$ photocatalysis alone. Although the mechanisms for enhancing oxidation are likely different between these treatment processes and BDD EO, iron enhancement is common among these processes. To the authors' knowledge, iron-enhanced BDD EO has not previously been investigated. Using an oxidation method like EO could also regulate iron oxidation to maximize disinfection and minimize soluble iron residuals. Conversely, EO may benefit EC by further oxidizing iron species to form more floc.

For this reason, the possible synergistic effects of ferrous iron generated by EC and EO performance was investigated. As shown in $\mathrm{SI} 3$, inclusion of a filtration step between $\mathrm{EC}$ and $\mathrm{EO}$ improved virus reduction beyond $\mathrm{EC}$ alone. Thus, ferrous iron from EC likely created an oxidant demand rather than enhancing EO. To confirm the effect of ferrous iron as an oxidant scavenger, a follow up experiment was performed using ferrous chloride to demonstrate the effect of ferrous iron dose on EO inactivation. Samples of the bulk solution after EO were homogenized and eluted ( $6 \%$ beef broth, $\mathrm{pH} 9.5$ ) to show the effect of inactivation only, without considering removal due to coagulation/destabilization. As shown in Fig. 3 , the oxidant demand of ferrous iron inhibited virus inactivation at low doses. At higher doses of ferrous iron, virus inactivation eventually met or exceeded the level achieved by EO without ferrous addition. Therefore, ferrous iron may catalyze virus inactivation, but the concentration of iron needed ( $>30 \mathrm{mg} / \mathrm{L}$ $\mathrm{Fe}$ ) to do so may be cost-prohibitive and introduce high concentrations of residual iron. Based on these observations, one innovation of our study was to use a sequential EC-EO process and to include a separation step to remove iron precipitate prior to EO. Previous attempts to combine iron EC and EO processes have used a simultaneous EC/EO reactor that would likely be inhibited by the oxidant demand of ferrous iron (Llanos et al., 2014).

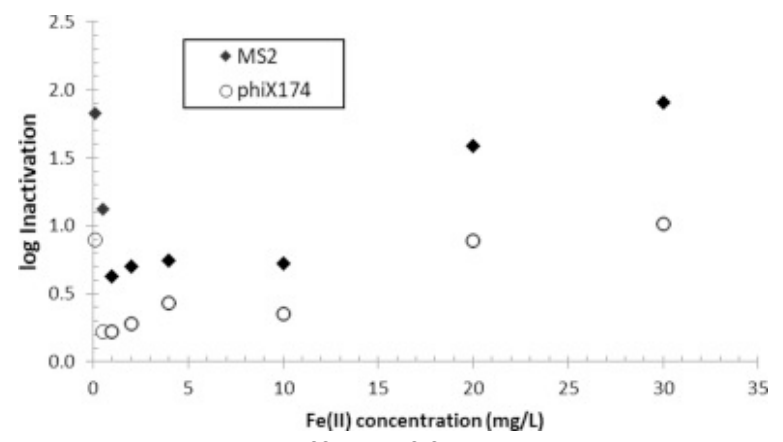

Fig. 3. Combined effect of ferrous chloride coagulation and subsequent boron-doped diamond electrooxidation on the reduction of bacteriophages MS2 and $\Phi \times 174$. Inactivation was inhibited by low doses of ferrous iron and returned to iron-free inactivation levels only at very high doses $(\sim 30 \mathrm{mg} / \mathrm{L} \mathrm{Fe})$. Tests were conducted in $2.1 \mathrm{mM} \mathrm{NaHCO}_{3}, \mathrm{pH}$ 7. Points represent single tests (mean of 10 counts). 


\subsection{Sequential EC-EO treatment of model waters}

\subsubsection{Charge allocation for optimal EC-EO virus mitigation}

The impact of energy allocation between EC and EO in the EC-EO treatment train was evaluated to determine how the two processes might be balanced for enhanced virus reduction. The total charge loading of $150 \mathrm{C} / \mathrm{L}$ for EC-EO treatment and retention time of 5 min per process were held constant while current allocated to each treatment varied. Increased charge allocation to EC from $0 \%$ to $100 \%$ (0$100 \mathrm{~mA}$ ) was approximately equal to the increase in energy density $\left(\mathrm{kWh} / \mathrm{m}^{3}\right.$, or energy normalized to the reactor volume) for EC and EO, as shown in SI 5. Here, virus mitigation was related to charge allocation so that the results could be generalized to other EC and EO reactors. These charge allocation tests were conducted in each of the four model waters representing a wide range of environmental source waters (summarized in Table 1).

The effect of charge allocation on MS2 and $\Phi$ X174 bacteriophage removal is shown in Fig. 4 for the four model waters. Charge allocation was arbitrarily represented as a percentage of the total charge loading allocated to EC. Regression models expressing log reduction in terms of percent charge allocated to EC are summarized in Table 2, including estimated optimal charge allocation in each source water. Both surface waters (Lake Michigan and Mississippi River) tended to favor the dual process of EC-EO, with optimal charge allocated to EC of 47\% (both MS2 and ФX174) in Lake Michigan model water and 60\% (MS2) or 26\% (ФX174) in Mississippi River model water. Sandstone Aquifer model groundwater favored EC alone, while Dolomite Aquifer model groundwater showed no significant trend, with similar removal across the charge allocation range. The main difference in formulation between these two waters was the chloride concentration (see Table 1), with Sandstone Aquifer comprising very little chloride (4 mg/L $\left.\mathrm{Cl}^{-}\right)$and Dolomite an excess of chloride $\left(70 \mathrm{mg} / \mathrm{L} \mathrm{Cl}^{-}\right)$. Evolution of free chlorine was therefore likely to have improved disinfection by EO, as previous researchers have also reported (Lacasa et al., 2013; Mascia et al., 2013; Polcaro et al., 2009; Rajab et al., 2015). Nevertheless, EO still did not surpass $\mathrm{EC}$ in Dolomite Aquifer model water.

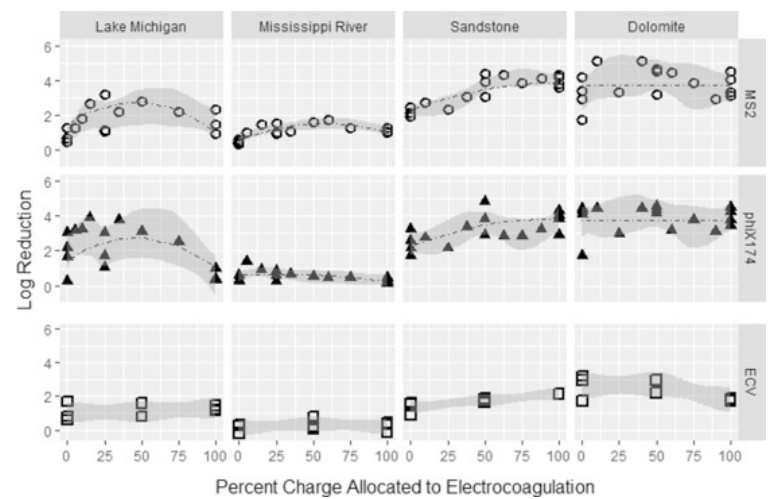

Fig. 4. The effect of charge allocation between iron electrocoagulation and boron-doped diamond electrooxidation on the reduction of bacteriophages MS2 and ФX174 and human echovirus 12 (ECV) in four model waters. Poorest removal occurred in Mississippi River water (the highest in NOM and turbidity), while greatest average removal occurred in Dolomite Aquifer (the highest in conductivity and chloride). Points represent single tests (mean of 10 counts for bacteriophages, single well plates for ECV); lines represent predicted values based on regression models. ECV data was insufficient to characterize over the entire range of charge allocation. 
Table 2. Summary of linear regression models for log reduction of bacteriophage MS2 and $\Phi \times 174$ as a function of the percent of the total charge used in the EC-EO treatment process $(150 \mathrm{C} / \mathrm{L})$ that was allocated to EC ("\% EC"). Estimated optimal charge allocation based on the regression models ranged from $26 \%$ to $100 \%$ EC. A single model described log reduction of both MS2 and DX174 for all waters except Mississippi River. Log reduction in the Dolomite Aquifer model water was independent of charge allocation, so there was no optimal \% EC.

\begin{tabular}{|c|c|c|c|c|c|c|c|c|c|}
\hline & & $\begin{array}{l}\text { Lake } \\
\text { Michigan }\end{array}$ & & $\begin{array}{l}\text { Mississippi } \\
\text { River }\end{array}$ & & $\begin{array}{l}\text { Sandstone } \\
\text { Aquifer }\end{array}$ & & $\begin{array}{l}\text { Dolomite } \\
\text { Aquifer }\end{array}$ & \\
\hline & & MS2 & ФX174 & MS2 & ФX174 & MS2 & ФX174 & MS2 & ФX174 \\
\hline \multirow[t]{2}{*}{ Intercept } & $\beta$ & 1.46 & & 0.584 & 0.584 & 2.28 & & 3.53 & \\
\hline & $p$-value & $2.04 \mathrm{E}-05$ & & $1.50 \mathrm{E}-07$ & $\begin{array}{l}1.50 \mathrm{E}- \\
07\end{array}$ & $2.24 \mathrm{E}-13$ & & $<2 \mathrm{e}-16$ & \\
\hline \multirow[t]{2}{*}{$\% \mathrm{EC}$} & $\beta$ & 0.0557 & & 0.0313 & 0.00438 & 0.0329 & & n.s & \\
\hline & $p$-value & $5.21 \mathrm{E}-03$ & & $1.49 \mathrm{E}-05$ & $\begin{array}{l}5.72 \mathrm{E}- \\
04\end{array}$ & $1.39 \mathrm{E}-03$ & & n.s & \\
\hline \multirow[t]{2}{*}{$(\% E C)^{2}$} & $\beta$ & $\begin{array}{l}-5.96 \mathrm{E}- \\
04 \\
\end{array}$ & & $-2.63 \mathrm{E}-04$ & $\begin{array}{l}-7.62 \mathrm{E}- \\
05\end{array}$ & $-1.74 \mathrm{E}-04$ & & n.s & \\
\hline & $p$-value & $2.24 \mathrm{E}-03$ & & $2.00 \mathrm{E}-04$ & $\begin{array}{l}2.39 \mathrm{E}- \\
02\end{array}$ & $6.32 \mathrm{E}-02$ a & & n.s & \\
\hline $\begin{array}{l}\text { Estimated } \\
\text { optimal \% } \\
\text { EC }\end{array}$ & & $47 \%$ & & $60 \%$ & $26 \%$ & $100 \%$ & & N/A & \\
\hline $\begin{array}{l}\text { F statistic } \\
\text { (degrees of } \\
\text { freedom) }\end{array}$ & & $\begin{array}{l}6.047 \\
(2,29)\end{array}$ & & $\begin{array}{l}14.28(4, \\
27)\end{array}$ & & $\begin{array}{l}20.15 \\
(2,31)\end{array}$ & & $\mathrm{N} / \mathrm{A}$ & \\
\hline$R_{\text {adj }}^{2}$ & & 0.25 & & 0.63 & & 0.54 & & $\mathrm{~N} / \mathrm{A}$ & \\
\hline
\end{tabular}

n.s: Not significant.

N/A: Not applicable as log reduction was independent of charge allocation.

aVariable was not strictly significant $(\alpha=0.05)$ but was determined to be beneficial to the model by Aikake's An Information Criterion (AIC).

This trend was somewhat surprising because model groundwaters had a lower $\mathrm{pH}(\mathrm{pH} 7.5)$ than surface waters ( $\mathrm{pH}$ 8.1-8.25). During the EC-EO process, $\mathrm{pH}$ increased slightly in all model waters but did not increase disproportionately for surface waters, as shown in SI 5. Therefore, EO was expected to be more effective in groundwaters than surface waters. In fact, log reduction was overall greater in groundwaters. This indicates that low $\mathrm{pH}$ improved virus mitigation via EC to an even greater extent than EO. Previous research (Heffron et al., 2019a) has demonstrated that inactivation via iron EC increases at lower $\mathrm{pH}$ levels and may even become the dominant fate of viruses. Bacteriophage inactivation is a function of both the amount of iron oxidation and the iron oxidation rate (Heffron et al. 2019b). Because the groundwaters had low initial pH and dissolved oxygen concentrations, greater ferrous concentrations were maintained in solution, as shown in SI 6. In low-oxygen conditions, ferrous iron requires a longer time to oxidize (Stumm and Lee, 1961). Therefore, model groundwaters offered a more favorable environment for virus inactivation due to ferrous iron.

As anticipated, the high NOM, high turbidity, and high pH Mississippi River water was the most challenging for virus reduction. Ferrous iron binds with NOM, thereby becoming resistant to oxidation (Crittenden et al., 2012). Accordingly, ferrous iron residual remained high after EO only in the high-NOM 
Mississippi River water (see SI 6). Therefore, NOM impairs not only the EO stage (ig. 3 ), but also EC. The failure of EC to dramatically improve virus mitigation in Mississippi River water is testament to the fact that EC did not substantially improve water quality prior to EO (in contrast to the original hypothesis). In Mississippi River water, total organic carbon did not significantly change between the initial concentration and post-EO filtration $(p=0.175)$. Decreasing $\mathrm{pH}$ prior to $\mathrm{EC}$ to achieve enhanced coagulation can improve NOM removal (Vepsäläinen et al., 2009). However, the tendency of EC to increase solution $\mathrm{pH}$ could counteract enhanced coagulation.

The electrical energy per order (EEO) for virus reduction further highlighted the efficacy of the overall treatment in model groundwaters over model surface waters, as shown in Fig. 5 . In a sequential treatment evenly divided between EC and EO ( $50 \mathrm{~mA}$ for $5 \mathrm{~min}$ in each stage), log virus reduction required approximately 2-10 times greater energy input in model surface waters compared to groundwaters. The greater energy density requirements are due not only to poorer virus mitigation in surface waters, but also the higher potentials needed to overcome resistance due to low conductivity (see Table 1). Though EEO provides a benchmark for comparing virus mitigation in the different model water matrices used in this study, using EEO to compare to other technologies is potentially problematic. The batch EC and EO reactors used in this study were not optimized for energy efficiency, so comparisons to established technologies are not possible. In addition, a lack of standard experimental conditions for assessing EEO makes comparisons between even studies using the same technology problematic (Litter et al., 2018). With these caveats in mind, it is still possible to compare the order of magnitude of EEOs in this study to other values. An EEO of $<0.265 \mathrm{~kW} / \mathrm{m}^{3}$ is generally recommended, although higher values have been used in cases where there are no treatment alternatives (Crittenden et al., 2012). Fig. 5 shows that groundwater treatment using EC-EO for virus mitigation falls within the recommended range, even without any attempt to optimize the process for power efficiency.

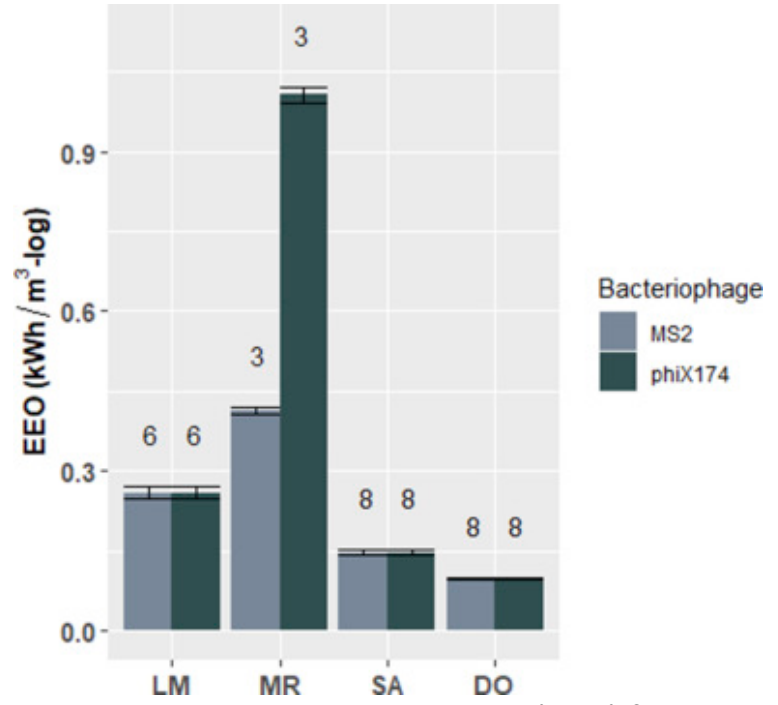

Fig. 5. Electrical energy per order (EEO) for the sequential electrocoagulation - electrooxidation treatment train in four model waters. Though the batch reactors used in this study were not optimized for energy efficiency, EEO provides a benchmark for comparing the energy cost of virus mitigation between different water matrices. Log reduction was estimated in each water for an even distribution of charge between electrocoagulation and electrooxidation ( $50 \mathrm{~mA}$ for $5 \mathrm{~min}$, or $75 \mathrm{C} / \mathrm{L}$, per process) using the regression models shown in Table 2. $\mathrm{LM}=$ Lake Michigan, $\mathrm{MR}=$ Mississippi River, $\mathrm{SA}=$ Sandstone 
Aquifer, and $\mathrm{DO}=$ Dolomite Aquifer model waters. Each column represents the mean values of replicate tests ( $\mathrm{n}$ shown above bars) with \pm 1 standard error shown by the error bars.

Though the trends modeled in Fig. 4 were significant, triplicate tests of virus mitigation did not significantly differ between a balance of EC-EO and EC alone. These results indicated that EC alone was nearly as effective as the sequential EC-EO treatment. Ferrous iron concentrations entering the EO stage

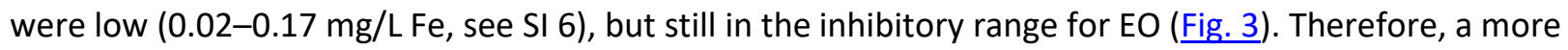
effective particle separation stage, e.g., microfiltration, could lead to greater disinfection in the EO stage. Given the relative cost of iron and BDD electrodes, a one-stage EC treatment would be far preferable for virus mitigation from a practical standpoint. In addition, the combination of ROS and chlorine species formed by BDD electrodes can give rise to disinfection byproducts (DBPs) like chlorate and perchlorate unless operating conditions are carefully controlled (Polcaro et al., 2009; Rajab et al., 2015). However, EO may still offer benefits for oxidizing other contaminants, such as organic micropollutants. EO also oxidized residual ferrous iron after EC for most waters (see SI 6). EO can therefore act as a polishing step to oxidize residual iron for improved precipitation and removal in order to meet aesthetic standards for iron in drinking water.

\subsubsection{Comparison of bacteriophage surrogates to human echovirus 12}

Reduction of echovirus by the EC-EO treatment train was also evaluated in the four model waters, as shown in Fig. 4. Echovirus mitigation followed the same pattern as bacteriophages, in order of increasing reduction: Mississippi River < Lake Michigan < Sandstone Aquifer $\approx$ Dolomite Aquifer (as summarized in SI 2). However, the mean reduction of echovirus was significantly less than one or both bacteriophage surrogates in all model waters by a factor of 0.9-1.5 logs, as summarized in Table 3. By contrast, the two bacteriophages significantly differed only in Mississippi River model water, where removal followed the pattern of echovirus $\approx \Phi \times 174<$ MS2.

Table 3. Comparison of bacteriophage surrogates MS2 and $\Phi \times 174$ and human echovirus 12 (ECV) reduction due to sequential electrocoagulation-electrooxidation treatment. Mean reduction from all tests in each model water was compared by Tukey's HSD. Entries in bold indicate significant differences $(\alpha=0.05)$.

\begin{tabular}{|l|l|l|l|}
\hline Water Matrix & $\begin{array}{l}\text { Mean Difference in Log Reduction } \\
\text { and Significance (Adjusted p-value) }\end{array}$ & & \\
\hline & MS2 - ECV & ФX174 - ECV & MS2 - ФX174 \\
\hline Lake Michigan & 0.660 & 1.266 & -0.606 \\
\hline & $p=2.53 E-01$ & $p=9.73 E-03$ & $p=1.69 E-01$ \\
\hline Mississippi River & 0.876 & 0.420 & 0.457 \\
\hline & $p=1.76 E-05$ & $p=4.59 E-02$ & $p=4.72 E-03$ \\
\hline Sandstone Aquifer & 1.503 & 1.334 & 0.169 \\
\hline & $p=2.58 E-05$ & $p=1.64 E-04$ & $p=7.57 E-01$ \\
\hline Dolomite Aquifer & 1.092 & 1.213 & -0.122 \\
\hline & $p=2.27 E-02$ & $p=1.02 E-02$ & $p=9.20 E-01$ \\
\hline
\end{tabular}

Mitigation of bacteriophage MS2 was significantly higher in Mississippi River model water than either ФX174 or echovirus, which indicates that bacteriophage ФX174 mitigation is impaired to a greater degree by NOM and turbidity. As discussed in Section 3.1, NOM and turbidity can dramatically impact 
the efficacy of EO. NOM also impairs virus mitigation by iron EC (ㅂeffron et al., 2019a; Tanneru and Chellam, 2012). Though neither phage was a conservative surrogate, the lack of a significant difference in echovirus and $\Phi \times 174$ mitigation in Mississippi River model water indicates that $\Phi \times 174$ should be considered the more conservative surrogate for human viruses across a range of waters. In addition, the difference in mean log reduction between bacteriophage $\Phi$ X174 and echovirus was consistent across model waters (between 2 and 3 times greater log reduction). Until a better surrogate is identified, correcting bacteriophage $\Phi$ X174 inactivation results by a safety factor of 2-log reduction could provide a reasonable indicator of echovirus mitigation.

\subsubsection{Comparison to conventional coagulation/disinfection}

The EC-EO treatment train was compared to a conventional treatment train of chemical coagulation with ferric chloride salt ( $22 \mathrm{mg} \mathrm{Fe} / \mathrm{L}$, equivalent to the iron generated by EC at $50 \mathrm{~mA}$ for $5 \mathrm{~min}$ ) and free chlorine $\left(1.2 \mathrm{mg} / \mathrm{L} \mathrm{Cl}_{2}\right)$. The purpose of this comparison was to evaluate the relative efficacy of EC-EO compared to typical treatment processes under identical water quality conditions. Although the iron dose was equivalent to the EC dose for Dolomite Aquifer and Sandstone Aquifer model groundwaters, these tests did not provide a mechanistic comparison to the conventional treatment train as they did not account for ferrous oxidation, generation of ROS, or anodic oxidation.

In the Lake Michigan and Mississippi River model surface waters, the conventional treatment system outperformed the EC-EO system, as shown in Fig. 6. However, in the model Sandstone and Dolomite Aquifer groundwaters, EC-EO dramatically outperformed the conventional system. This discrepancy may be due to iron-based disinfection in low-oxygen waters, as discussed in Section 3.3.1. In addition, the two surface waters were above $\mathrm{pH} 8$, leading to poor conditions for disinfection by either free chlorine or hydroxyl radicals. Addition of chemical coagulant decreased the $\mathrm{pH}$ to 7.0 or less in all waters, which likely improved disinfection by ensuring free chlorine was predominately in the hypochlorous acid, rather than the hypochlorite, form.

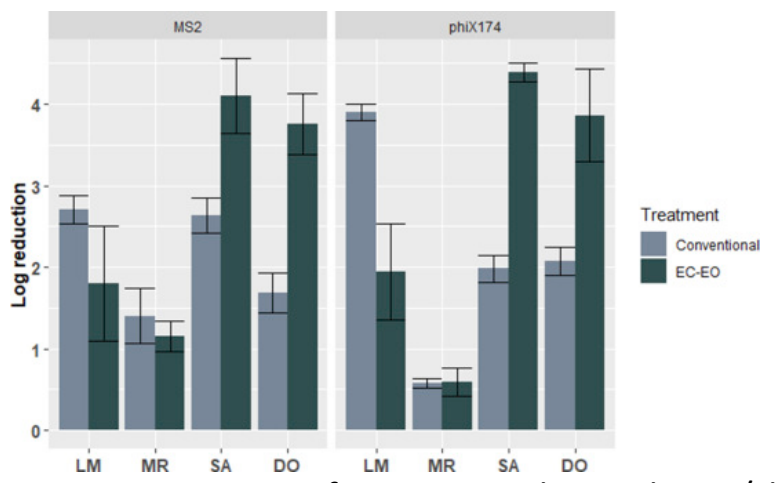

Fig. 6. Comparison of conventional coagulation/chlorination treatment train to the electrocoagulationelectrooxidation (EC-EO) treatment train for the reduction of bacteriophages MS2 and ФX174.

"Conventional" treatment consisted of $\mathrm{FeCl}_{3}$ chemical coagulation $(22 \mathrm{mg} / \mathrm{L} \mathrm{Fe}$ ) followed by $\mathrm{NaOCl}$ disinfection ( $6 \mathrm{mg}-\mathrm{min} / \mathrm{L} \mathrm{Cl}_{2}$ ). EC-EO was conducted near the optimal division of $150 \mathrm{C} / \mathrm{L}$ in the EC-EO treatment train (25\% EC for LM and MR, 50\% EC for DO and SA). LM = Lake Michigan, MR = Mississippi River, $\mathrm{SA}=$ Sandstone Aquifer, and DO = Dolomite Aquifer model waters. Each column represents the mean values of triplicate tests with \pm 1 standard error shown by the error bars.

Even when conventional treatment outperforms EC-EO, logistical considerations may favor one water treatment train over the other. On one hand, the EC-EO treatment system requires further power 
optimization to be feasible for large-scale surface water applications. On the other, the system's portability, potential for automation, and lack of caustic chemical additions make EC-EO a viable option for small-scale, distributed treatment. The cost of BDD electrodes is a major hurdle to implementing an EC-EO treatment process. However, EO may provide other benefits not considered here, e.g., the oxidation of organic micropollutants or residual iron from EC treatment. As new, more cost-effective EO electrodes are developed, the combined EC-EO process will become more attractive as an alternative to conventional drinking water treatment.

\section{Conclusions}

Few studies have assessed EC and EO individually for virus mitigation, and no previous research has investigated an EC-EO process for virus mitigation. This study both establishes a basis for using a novel, sequential EC-EO treatment train for drinking water and thoroughly evaluates treatment performance for two bacteriophages and a human waterborne virus. Neither bacteriophage was a conservative surrogate for human echovirus, although $\Phi$ X174 was a better predictor of echovirus mitigation.

Though the EC-EO treatment system proposed in this study was not beneficial in all water matrices, the improved virus mitigation achieved by EC-EO in model surface waters warrants further attention. The benefit of EC-EO was probably not due to iron-enhanced oxidation. Instead, greater virus reduction observed in the EC-EO treatment train was likely achieved by the additive effects of physical removal via coagulation/filtration, ferrous iron-based disinfection, and EO disinfection.

\section{Acknowledgments}

Partial funding for this project was provided by the Lafferty Family Foundation. Mr. Heffron was also partially supported by a Richard W. Jobling Research Assistantship and a fellowship from the Arthur J. Schmitt Foundation. The authors do not claim any competing interests.

\section{Appendix A. Supplementary data}

The following is the Supplementary data to this article:

Sequential electrocoagulation-electrooxidation for virus mitigation in drinking water

Joe Heffron ${ }^{\mathrm{a}}$, Donald R. Ryan ${ }^{\mathrm{a}}$, Brooke K. Mayer ${ }^{\mathrm{a}^{*}}$

${ }^{a}$ Department of Civil, Construction and Environmental Engineering, Marquette University, Milwaukee, WI 53233

*Corresponding Author:

Department of Civil, Construction and Environmental Engineering, Marquette University, 1637 West Wisconsin Avenue, Milwaukee, WI 53233

Phone: 414-288-2161

Email: Brooke.Mayer@marquette.edu

The supporting information consists of 12 pages, including 6 sections, 1 table, and 7 figures:

SI 1: Effect of DMSO cryopreservant on electrooxidation 
SI 2: Basis for model water matrices

SI 3: Contribution of particle separation to the EC-EO treatment train

SI 4: Effect of total charge loading on bacteriophage removal

SI 5: Reactor performance during the EC-EO process

SI 6: Iron generation and residuals through the EC-EO process

\section{SI 1: Effect of DMSO cryopreservant on electrooxidation}

As shown in Figure $\mathrm{S} 1$, dimethyl sulfoxide (DMSO) inhibited bacteriophage inactivation due to borondoped diamond (BDD) electrooxidation (EO). For this reason, viruses were not stored with cryopreservant. Viruses were stored at $-20^{\circ} \mathrm{C}$ and used within 2 months of propagation to prevent significant loss of titer.

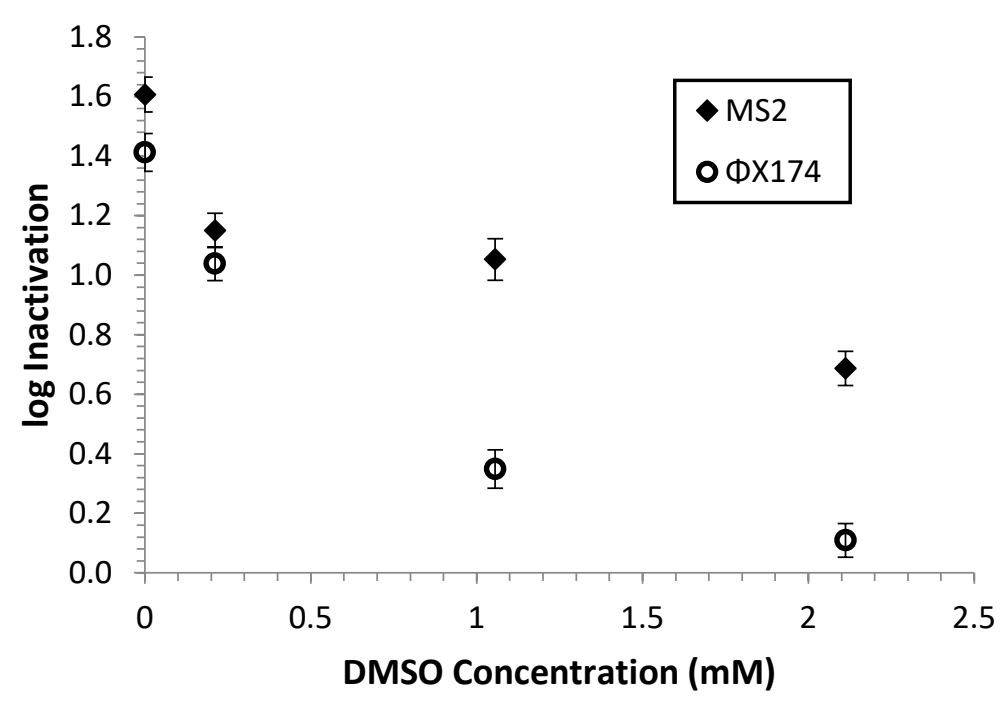

Figure S1. Effect of DMSO on removal of bacteriophages MS2 and $\Phi$ X174 due to electrooxidation (100 $\mathrm{mA}, 5 \mathrm{~min}$ ) in $2.1 \mathrm{mM} \mathrm{NaHCO}_{3}$. Error bars represent \pm 1 standard error of mean plaque count $(\mathrm{n}=10)$ for single tests.

\section{SI 2: Basis for model water matrices}

The four model waters used in this study (Table S1) were based on empirical values for water at four sites. Lake Michigan model water was based on median water parameters of Milwaukee Water Works source water in 2016 (Milwaukee Water Works, 2017). For Mississippi River model water, water quality data for United States Geological Survey (USGS) site 05288500 (Mississippi River at Hwy. 610 in Brooklyn Park, MN) was accessed via the USGS National Water Information System (NWIS) web interface (USGS, 2006). This sampling site was chosen based on breadth of water quality data and location in the upper Midwest US, similar to the other waters evaluated. Median values of water quality data ranging from 1996 to 2006 were used as the basis for Mississippi River model water. Dolomite Aquifer model water was a composite of shallow aquifer data from Kewaunee and Waukesha Counties, WI (Bonness and Masarik, 2014; Waukesha Water Utility, 2002). Sandstone Aquifer model water was based on deep aquifer data from Waukesha, WI (Waukesha Water Utility, 2002). 
Reagent-grade $\mathrm{KCl}$ was added to achieve target chloride levels. Reagent-grade $\mathrm{NaHCO}_{3}$ was then added to achieve target conductivity and approximate alkalinity. Test water $\mathrm{pH}$ was adjusted with $\mathrm{H}_{2} \mathrm{SO}_{4}$ to add sulfates found at the ppm level in environmental waters. A2 test dust and humic acid sodium salt were added to increase turbidity and natural organic matter (NOM), respectively. Hardness was not included in test water formulations because adding soluble $\mathrm{CaCl}_{2}$ or $\mathrm{MgCl}_{2}$ salt would often result in chloride concentrations many times greater than target levels. 
Table S1. Empirical water quality data used to formulate model waters used in this study. Mississippi River data represents the median of water quality measurements between 1996 and 2006. Kewaunee groundwater data represents the median of water quality measurements in 10 wells in Lincoln Township, Kewaunee County.

\begin{tabular}{|c|c|c|c|c|c|c|c|c|c|c|c|}
\hline Water Source & $\begin{array}{l}\text { Associated } \\
\text { Model Water }\end{array}$ & $\begin{array}{l}\text { Conductivit } \\
\mathrm{y}(\mu \mathrm{S} / \mathrm{cm})\end{array}$ & $\begin{array}{l}\text { Alkalinity } \\
\text { (mg/L as } \\
\left.\mathrm{CaCO}_{3}\right)\end{array}$ & $\begin{array}{l}\text { Hardness } \\
(\mathrm{mg} / \mathrm{L} \text { as } \\
\left.\mathrm{CaCO}_{3}\right)\end{array}$ & $\begin{array}{l}\text { Total Organic } \\
\text { Carbon (mg/L) }\end{array}$ & $\begin{array}{l}\text { Chloride } \\
\text { (mg/L) }\end{array}$ & $\begin{array}{l}\text { Sodium } \\
\text { (mg/L) }\end{array}$ & $\mathrm{pH}$ & $\begin{array}{l}\text { Turbidity } \\
\text { (NTU) }\end{array}$ & $\begin{array}{l}\text { Sulfate } \\
\text { (mg/L) }\end{array}$ & Source \\
\hline $\begin{array}{l}\text { Lake } \\
\text { Michigan }\end{array}$ & Lake Michigan & 303 & 118 & 137 & 1.9 & 12.6 & 8.65 & $\begin{array}{l}8.2 \\
5\end{array}$ & 1 & 21.9 & $\begin{array}{l}\text { (Milwaukee } \\
\text { Water Works, } \\
\text { 2017) }\end{array}$ \\
\hline $\begin{array}{l}\text { Mississippi } \\
\text { River }\end{array}$ & $\begin{array}{l}\text { Mississippi } \\
\text { River }\end{array}$ & 359 & 162 & 180 & 8.65 & 11 & 7.7 & 8.1 & 30 & 13 & (USGS, 2006) \\
\hline $\begin{array}{l}\text { Waukesha } \\
\text { groundwater }\end{array}$ & $\begin{array}{l}\text { Sandstone } \\
\text { Aquifer }\end{array}$ & $\begin{array}{l}484 \\
(300 \mathrm{mg} / \mathrm{L} \\
\text { TDS) }\end{array}$ & 220 & 250 & & 4.1 & 40 & 7.5 & & & $\begin{array}{l}\text { (Waukesha Water } \\
\text { Utility, 2002) }\end{array}$ \\
\hline $\begin{array}{l}\text { Kewaunee } \\
\text { groundwater }\end{array}$ & $\begin{array}{l}\text { Dolomite } \\
\text { Aquifer }\end{array}$ & 774.5 & 323 & 413 & & 28.25 & & $\begin{array}{l}7.8 \\
2\end{array}$ & & 28.25 & $\begin{array}{l}\text { (Bonness and } \\
\text { Masarik, 2014) }\end{array}$ \\
\hline $\begin{array}{l}\text { Waukesha } \\
\text { groundwater }\end{array}$ & $\begin{array}{l}\text { Dolomite } \\
\text { Aquifer }\end{array}$ & $\begin{array}{l}871-758 \\
\text { (540 - } 470 \\
\mathrm{mg} / \mathrm{L} \text { TDS) }\end{array}$ & 320 & 420 & & 115 & 41.5 & 7.3 & & & $\begin{array}{l}\text { (Waukesha Water } \\
\text { Utility, 2002) }\end{array}$ \\
\hline
\end{tabular}




\section{SI 3: Contribution of particle separation to the EC-EO treatment train}

Figure $\mathrm{S} 2$ shows the contribution of three different treatment processes on the reduction of the bacteriophages using boron-doped diamond (BDD) electrodes for electrooxidation (EO): 1) EO only without electrocoagulation (EC) pretreatment, 2) EC with a post-particle filtration step, and 3) EC pretreatment without particle separation.

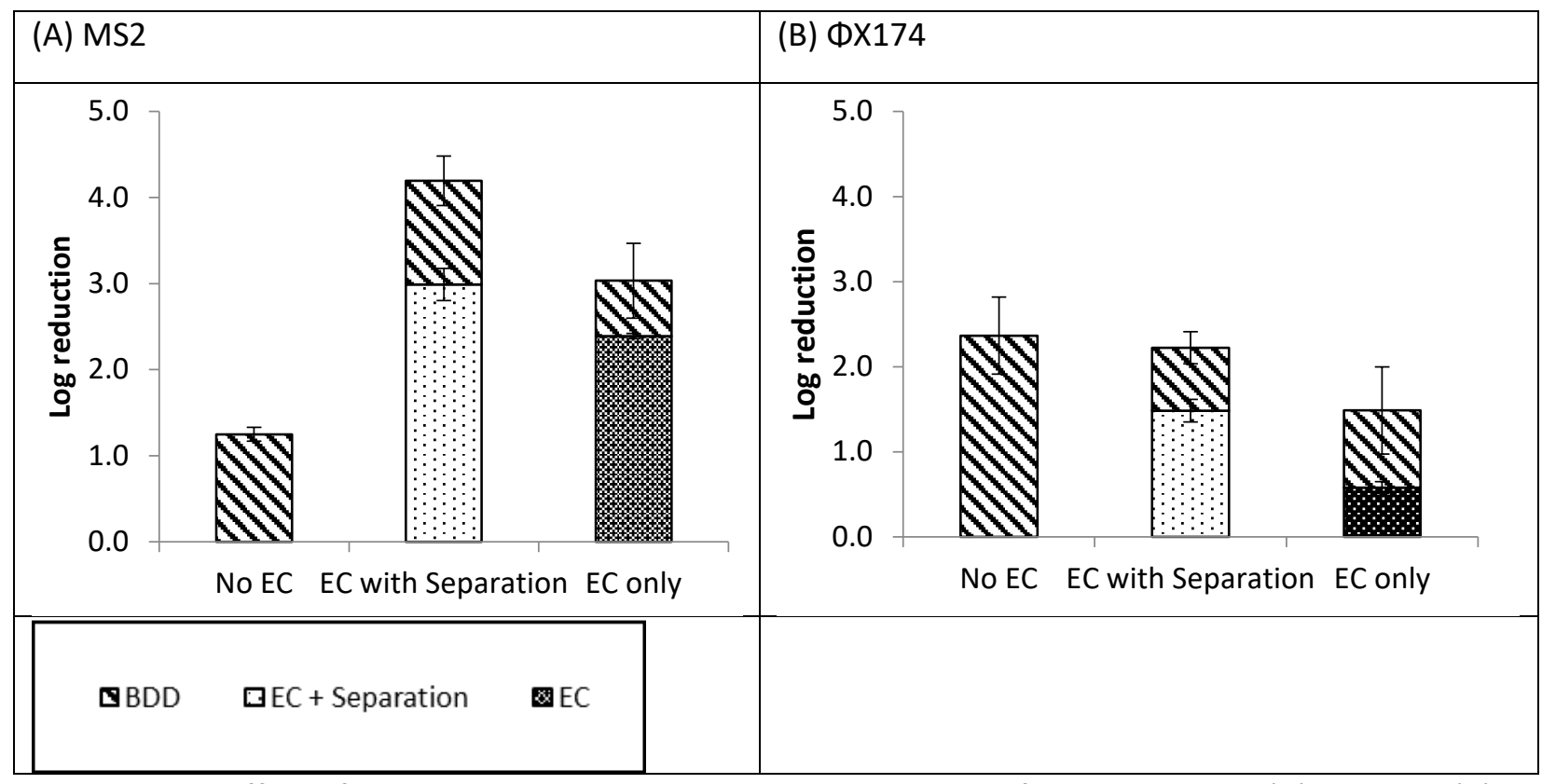

Figure S2. The effect of three treatment processes on the reduction of bacteriophages (A) MS2 and (B) DX174 by boron-doped diamond (BDD) electrooxidation: EO only (No EC), iron electrocoagulation followed by particle separation using a Whatman 114 filter (EC with Separation), and iron electrocoagulation with no particle separation (EC only). Particle separation after electrocoagulation improved overall virus reduction compared to electrocoagulation alone. Tests were conducted in $2.1 \mathrm{mM} \mathrm{NaHCO}_{3}, \mathrm{pH}$ 7. Each data point represents the mean values of triplicate tests with \pm 1 standard error shown by the error bars.

\section{SI 4: Effect of total charge loading on bacteriophage removal}

Three charge loadings $(300,150$, and $90 \mathrm{C} / \mathrm{L})$ were tested in Lake Michigan model water to determine an appropriate operating current for charge distribution tests in various model waters (Figure S3). Bacteriophage reduction using the $300 \mathrm{C} / \mathrm{L}$ electrocoagulation-electrooxidation (EC-EO) process exceeded the 4-log removal requirement set by the U.S. Environmental Protection Agency's (EPA) Surface Water Treatment Rule, and was thus used for all subsequent tests.

(A) MS2 


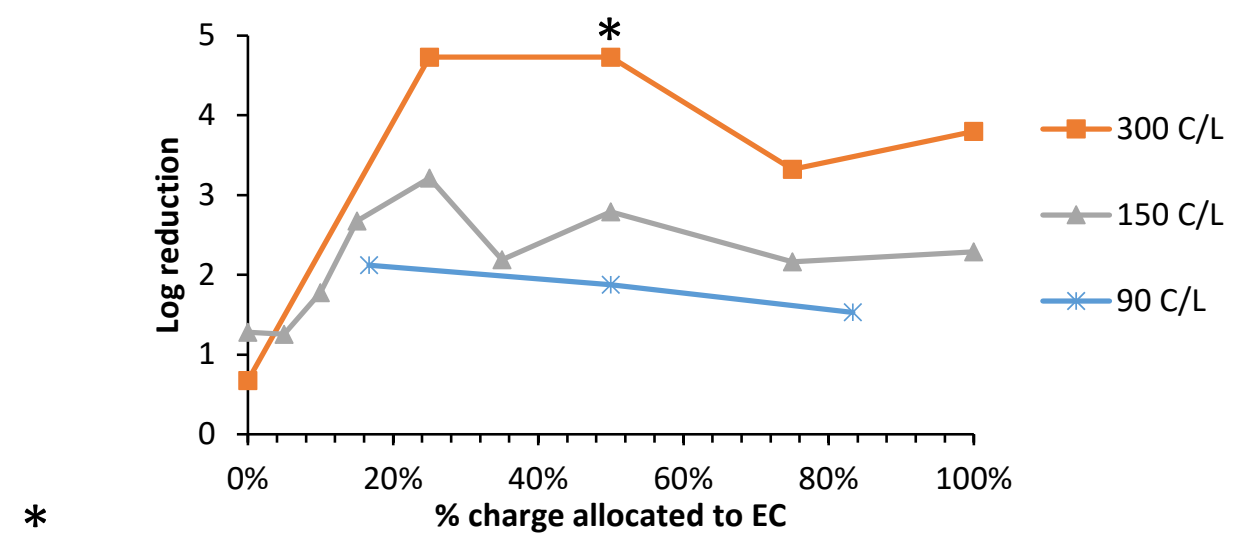

(B) $\Phi \times 174$

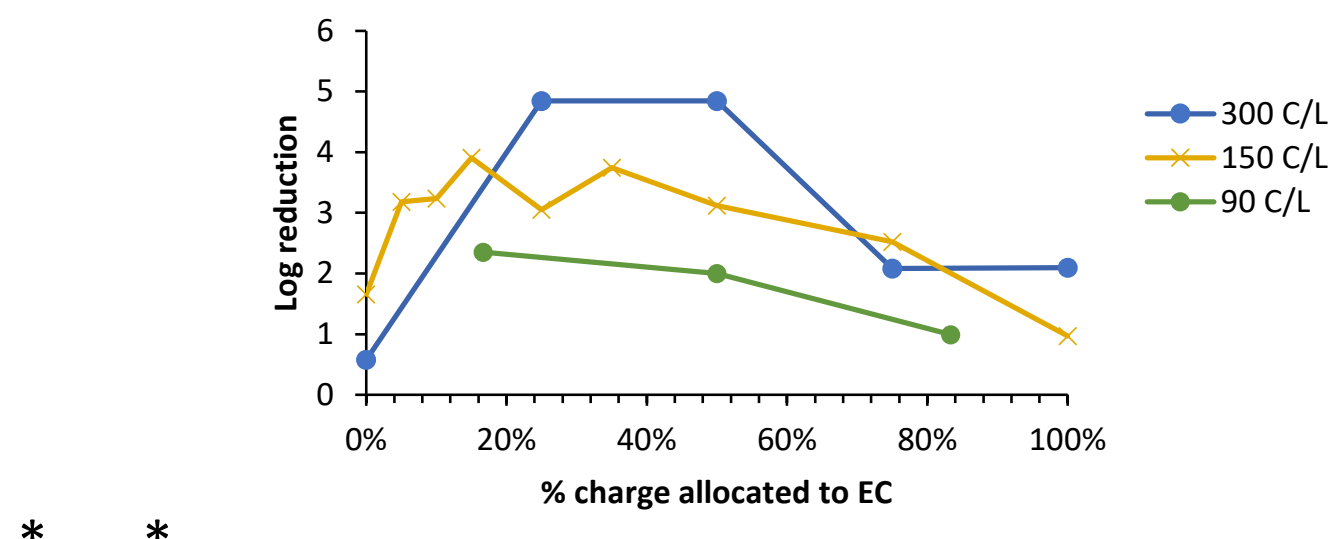

Figure S3. Reduction of bacteriophages (A) MS2 and (B) ФX174 showing the effect of total charge on charge distribution between electrocoagulation (EC) and electrooxidation (EO). Tests were performed in the Lake Michigan model water. The * symbol indicates virus removal beyond the countable limit.

\section{SI 5: Reactor performance during the EC-EO process}

During sequential EC-EO treatment, $\mathrm{pH}$ increased on average $0.41 \pm 0.25 \mathrm{pH}$ units, as shown in Figure S4. For Lake Michigan and Mississippi River model surface waters, the change in $\mathrm{pH}$ was positively correlated $(p=$ $8.2 \times 10^{-5} ; p=1.9 \times 10^{-5}$, respectively) with increasing charge allocation to EC rather than EO. EC can increase the $\mathrm{pH}$ of solution due to the reduction of water at the cathode producing more hydroxide ions than are incorporated into iron precipitates (Dubrawski and Mohseni, 2013). Sandstone Aquifer and Dolomite Aquifer model groundwaters were not significantly correlated with charge allocation to one process over another. 


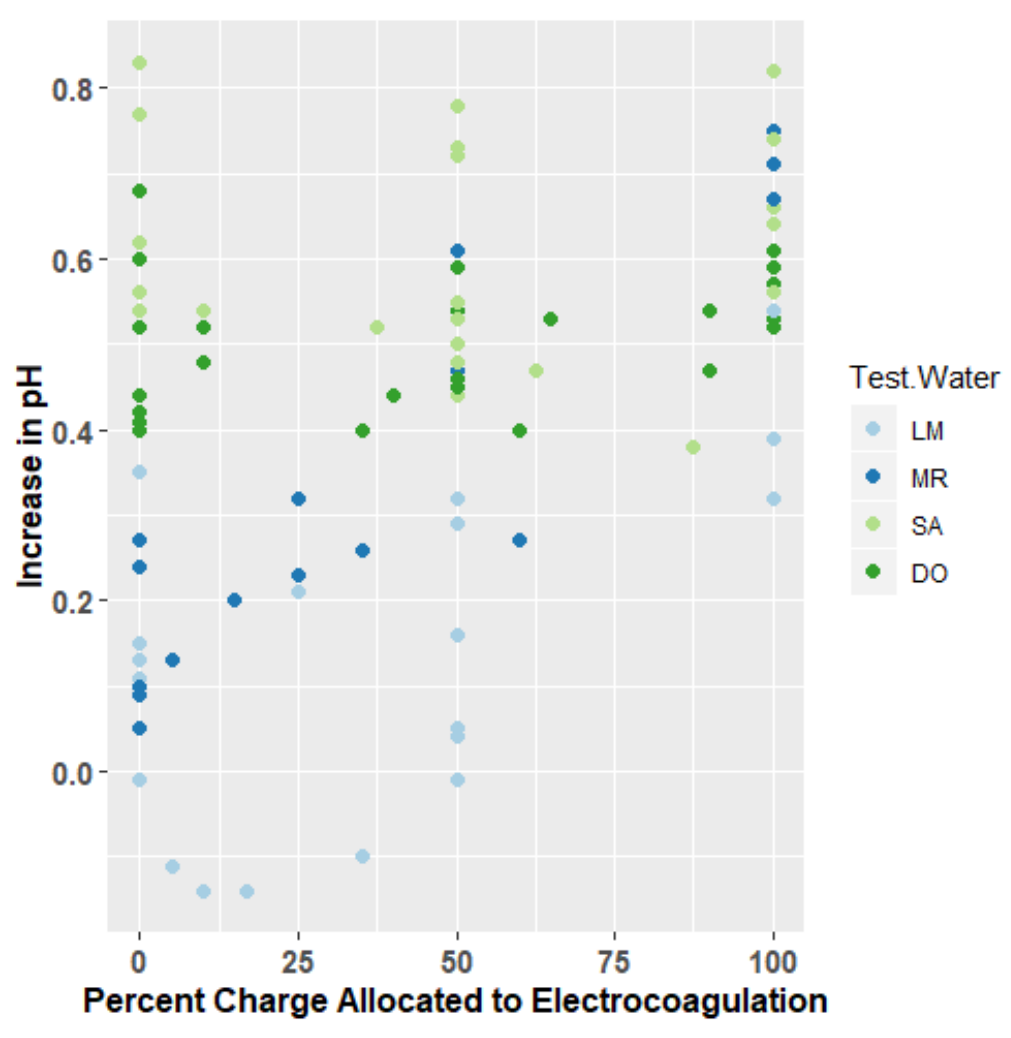

Figure S4. Increase in $\mathrm{pH}$ as a function of the percent of a constant charge loading $(150 \mathrm{C} / \mathrm{L})$ allocated between electrocoagulation (EC) and electrooxidation (EO). $L M=$ Lake Michigan, MR = Mississippi River, $S A=$ Sandstone Aquifer, and DO = Dolomite Aquifer model waters.

Figure $\mathrm{S} 5$ shows the energy density $\left(\mathrm{kWh} / \mathrm{m}^{3}\right.$, or energy input normalized to the reactor volume) required by each of the individual processes in the EC-EO treatment train. For the batch reactors used in this study, the energy required at a given current was approximately the same for EC and EO. Therefore, the percent of charge allocated to each process roughly mapped to the percent energy allocated. However, virus mitigation was related to charge allocation so that the results could be generalized to other EC and EO reactors. At $50 \%$ charge allocation, applied potentials were lowest due to even distribution of current; greater allocation to either EC or EO resulted in greater energy density due to exponentially increasing potential with increased current. Energy density at $50 \%$ charge allocation ranged from 0.12 to $0.41 \mathrm{kWh} / \mathrm{m}^{3}$ per process (or 0.31 to $0.79 \mathrm{kWh} / \mathrm{m}^{3}$ for the entire train). For perspective, most conventional drinking water treatment processes operate at $\leq 0.1 \mathrm{kWh} / \mathrm{m}^{3}$ (e.g., the energy consumption to provide a typical UV dose of $40 \mathrm{~mJ} / \mathrm{cm}^{2}$ ranges from approximately 0.003 to $0.025 \mathrm{kWh} / \mathrm{m}^{3}$ (Crittenden et al., 2012; Howe et al., 2012)). 


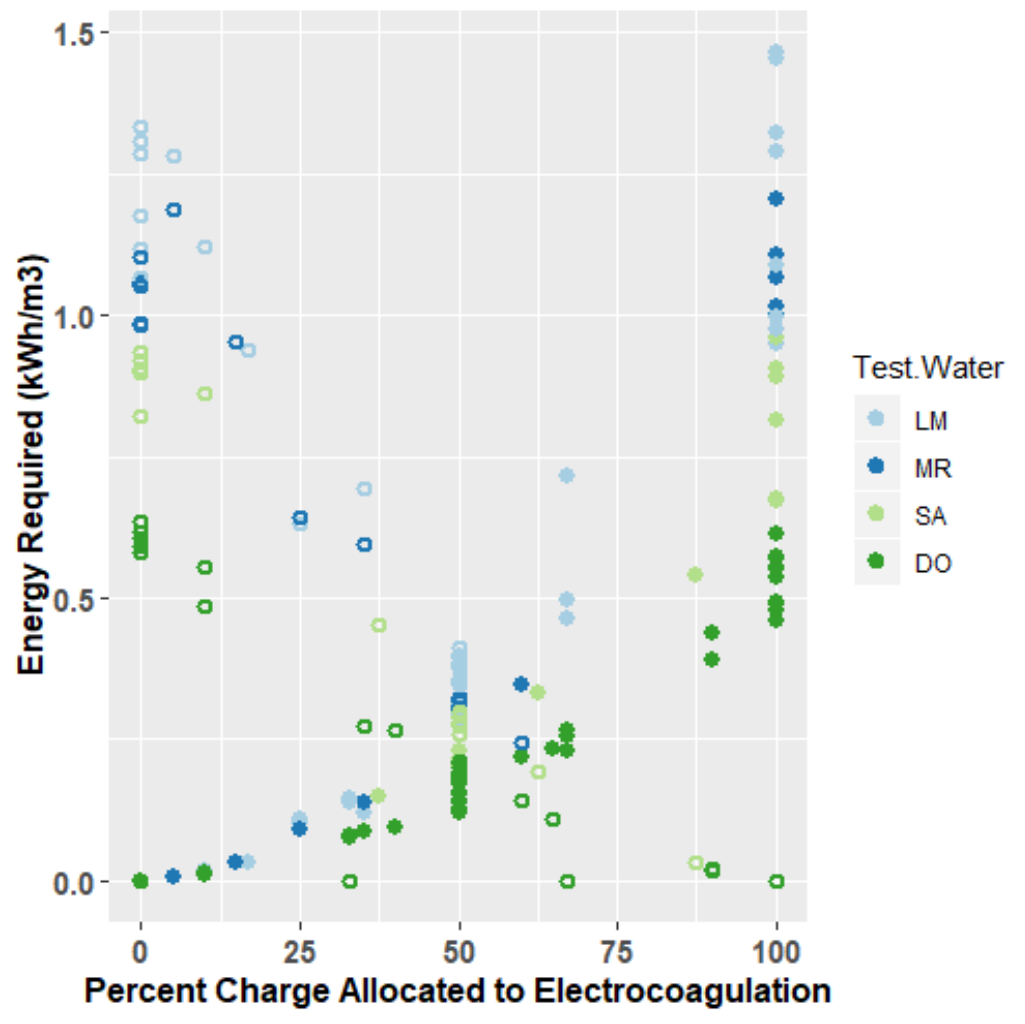

Figure S5. Energy required for electrocoagulation (filled circles) and electrooxidation (hollow circles) in a sequential electrocoagulation-electrooxidation treatment train. Energy usage was approximately symmetrical as a constant charge loading $(150 \mathrm{C} / \mathrm{L}$ ) was allocated from $100 \%$ electrooxidation ( $0 \%$ electrocoagulation) to $100 \%$ electrocoagulation. Energy requirements were inversely related to the conductivity of the model water, with decreasing energy from $\mathrm{LM}<\mathrm{MR}<\mathrm{SA}<\mathrm{DO}$. $\mathrm{LM}=$ Lake Michigan, $\mathrm{MR}=$ Mississippi River, $\mathrm{SA}=$ Sandstone Aquifer, and DO = Dolomite Aquifer model waters. 


\section{SI 6: Iron generation and residuals through the EC-EO process}

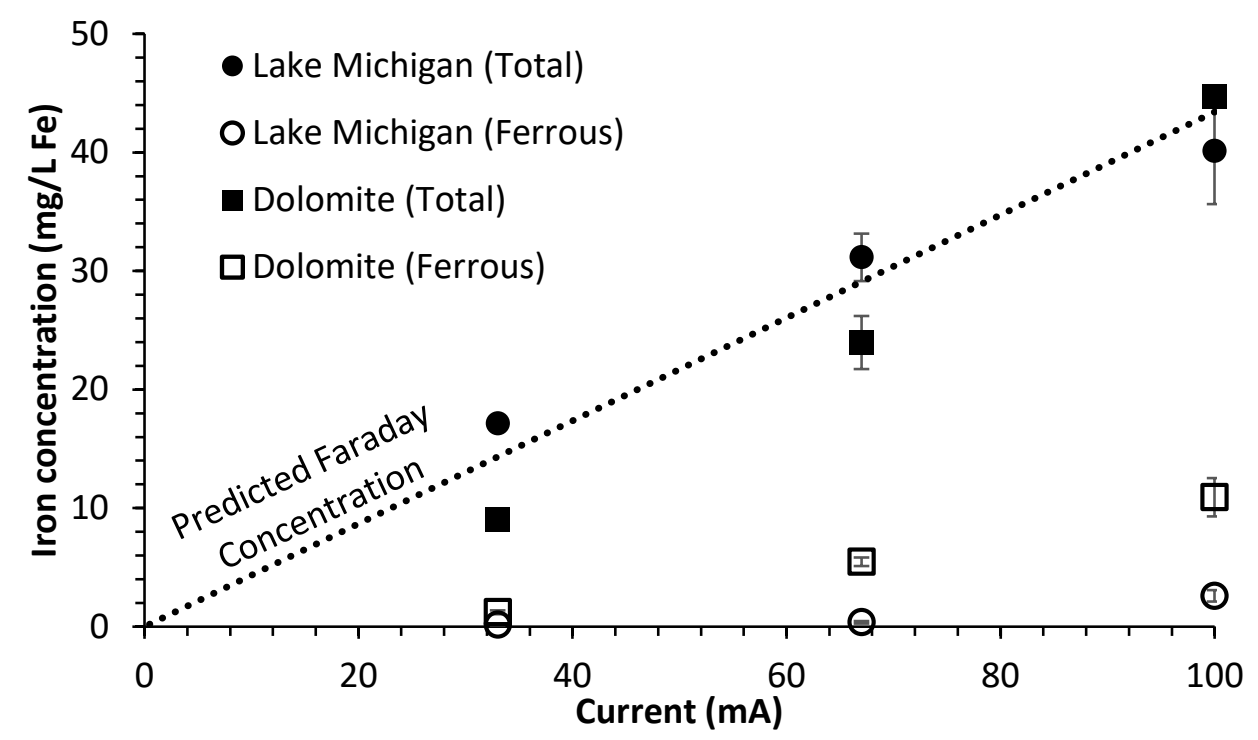

Figure S6. Total and ferrous iron generation by electrocoagulation (EC) as a function of current. Iron was generated by EC for 5 minutes in low-chloride, high-dissolved oxygen (DO) Lake Michigan model water and highchloride, low-DO Dolomite Aquifer model water. In both model waters, total iron was generated at high (9499\%) Faraday efficiency. Ferrous iron residual increased with current and was greater in the low-DO Dolomite Aquifer water. The rate of ferrous iron oxidation is proportional to the DO concentration (Stumm and Lee, 1961). 
(A) Ferrous iron residuals

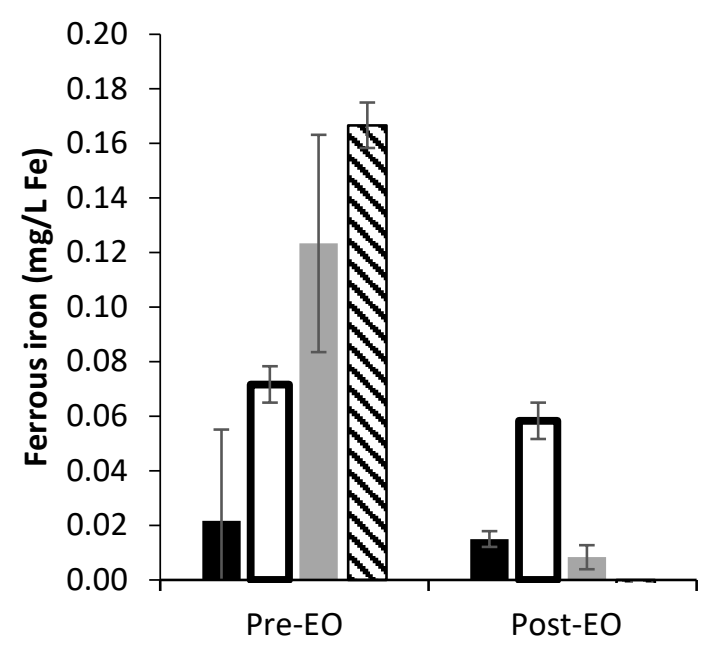

(B) Total iron residuals

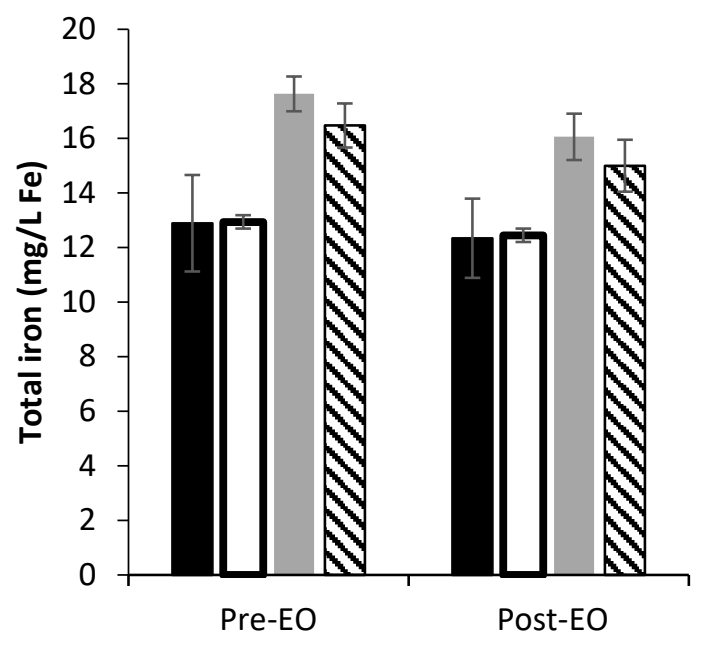

Figure S7. Total (A) and ferrous (B) iron residuals before and after electrooxidation (EO). Note the different scales of the $y$-axes. Iron concentrations were measured after coarse filtration with Whatman 114 filters. Pre-EO ferrous iron residuals were in the inhibitory range for EO, as shown in Figure 4 . While total iron residuals remained high ( $12-16 \mathrm{mg} / \mathrm{L} \mathrm{Fe}$ ) after final filtration (post-EO), post-EO ferrous iron concentrations were less than $0.02 \mathrm{mg} / \mathrm{L} \mathrm{Fe}$ in all model waters except Mississippi River water. Natural organic matter binds ferrous iron and prevents oxidation to the ferric state. These results indicate that a post-treatment stage is required for decreasing iron residuals, and EO may increase the effectiveness of iron removal by oxidizing ferrous iron to less soluble ferric iron.

\section{References}

Bonness, D., Masarik, K., 2014. Investigating Intra-annual Variability of Well Water Quality in Lincoln Township. Crittenden, J.C., Trussell, R.R., Hand, D.W., Howe, K.J., Tchobanoglous, G., 2012. MWH's Water Treatment:

Principles and Design, 3rd ed. John Wiley \& Sons, Inc., Hoboken, New Jersey.

Dubrawski, K.L., Mohseni, M., 2013. In-situ identification of iron electrocoagulation speciation and application for natural organic matter (NOM) removal. Water Res. 47, 5371-80. https://doi.org/10.1016/j.watres.2013.06.021

Howe, K.J., Hand, D.W., Crittenden, J.C., Trussell, R.R., Tchobanoglous, G., 2012. Principles of Water Treatment, 1st ed. John Wiley \& Sons, Inc, Hoboken, New Jersey.

Milwaukee Water Works, 2017. 2016 Quality of Lake Michigan Source Water.

Stumm, W., Lee, F.G., 1961. Oxygenation of ferrous iron. Ind. Eng. Chem. 53, 143-146. https://doi.org/10.1021/ie50614a030

USGS, 2006. NWIS Water Quality Samples (USGS 05288500) [WWW Document]. URL https://nwis.waterdata.usgs.gov/usa/nwis/qwdata/?site_no=05288500 (accessed 7.1.18).

Waukesha Water Utility, 2002. Waukesha Water Diversion Application, Appendix C: Future Water Supply Study.

\section{References}

Ahmadi and $\mathrm{Wu}, 2017$

A. Ahmadi, T. Wu. Inactivation of E. coli using a novel TiO2 nanotube electrode, Environ. Sci. Water Res. Technol., 3 (2017), pp. 534-545. https://doi.org/10.1039/C6EW00319B 
Amarasiri et al., 2017

M. Amarasiri, M. Kitajima, T.H. Nguyen, S. Okabe, D. Sano. Bacteriophage removal efficiency as a validation and operational monitoring tool for virus reduction in wastewater reclamation: Review. Water

Res., 121 (2017), pp. 258-269. https://doi.org/10.1016/j.watres.2017.05.035

Arslan-Alaton, 2001

I. Arslan-Alaton. Treatability of a simulated disperse dye-bath by ferrous iron coagulation, ozonation, and ferrous iron-catalyzed ozonation. J. Hazard Mater., 85 (2001), pp. 229-241. https://doi.org/10.1016/S0304$\underline{3894(01) 00232-1}$

Bagga et al., 2008

A. Bagga, S. Chellam, D.A. Clifford. Evaluation of iron chemical coagulation and electrocoagulation pretreatment for surface water microfiltration. J. Membr. Sci., 309 (2008), pp. 82-93. https://doi.org/10.1016/i.memsci.2007.10.009

Beck et al., 2009

N.K. Beck, K. Callahan, S.P. Nappier, H. Kim, M.D. Sobsey, J.S. Meschke. Development of a spot-titer culture assay for quantifying bacteria and viral indicators. J. Rapid Methods Autom. Microbiol., 17 (2009), pp. 455-464. https://doi.org/10.1111/i.1745-4581.2009.00182.x

Beltrán et al., 2005

F.J. Beltrán, F.J. Rivas, R. Montero-De-Espinosa. Iron type catalysts for the ozonation of oxalic acid in water. Water Res., 39 (2005), pp. 3553-3564. https://doi.org/10.1016/j.watres.2005.06.018

Ben-Sasson et al., 2011

M. Ben-Sasson, Y.M. Lin, a. Adin. Electrocoagulation-membrane filtration hybrid system for colloidal fouling mitigation of secondary-effluent. Separ. Purif. Technol., 82 (2011), pp. 63-70. https://doi.org/10.1016/j.seppur.2011.08.020

Bolton et al., 1996

J.R. Bolton, K.G. Bircher, W. Tumas, C.A. Tolman. Figures of merit for the technical development and application of advanced oxidation processes. J. Adv. Oxid. Technol., 1 (1996), pp. 1-11. https://doi.org/10.1515/jaots-1996-0104

Boudaud et al., 2012

N. Boudaud, C. Machinal, F. David, A. Fréval-Le Bourdonnec, J. Jossent, F. Bakanga, C. Arnal, M.P. Jaffrezic, S. Oberti, C. Gantzer. Removal of MS2, Q $\beta$ and GA bacteriophages during drinking water treatment at pilot scale. Water Res., 46 (2012), pp. 26512664. https://doi.org/10.1016/i.watres.2012.02.020

Bruguera-Casamada et al., 2017

C. Bruguera-Casamada, I. Sirés, E. Brillas, R.M. Araujo. Effect of electrogenerated hydroxyl radicals, active chlorine and organic matter on the electrochemical inactivation of Pseudomonas aeruginosa using BDD and dimensionally stable anodes. Separ. Purif. Technol., 178 (2017), pp. 224-231. https://doi.org/10.1016/j.seppur.2017.01.042

Bruguera-Casamada et al., 2016

C. Bruguera-Casamada, I. Sires, M.J. Prieto, E. Brillas, R.M. Araujo. The ability of electrochemical oxidation with a BDD anode to inactivate Gram-negative and Gram-positive bacteria in low conductivity sulfate medium. Chemosphere, 163 (2016), pp. 516-524. https://doi.org/10.1016/i.chemosphere.2016.08.042

Centers for Disease Control and Prevention, 2017

Centers for Disease Control and Prevention. Waterborne Disease \& outbreak surveillance reports. https://www.cdc.gov/healthywater/surveillance/surveillance-reports.html (2017)

Cossali et al., 2016 
G. Cossali, E.J. Routledge, M.S. Ratcliffe, H. Blakes, T.G. Karayiannis. Inactivation of E. coli, Legionella and Pseudomonas in tap water using electrochemical disinfection. J. Environ. Eng., 142 (2016). 04016063. https://doi.org/10.1061/(ASCE)EE.1943-7870.0001134

Cotillas et al., 2013

S. Cotillas, J. Llanos, P. Cañizares, S. Mateo, M.A. Rodrigo. Optimization of an integrated electrodisinfection/electrocoagulation process with Al bipolar electrodes for urban wastewater reclamation. Water Res., 47 (2013), pp. 1741-1750. https://doi.org/10.1016/j.watres.2012.12.029

Craun et al., 2010

G.F. Craun, J.M. Brunkard, J.S. Yoder, V.A. Roberts, J. Carpenter, T. Wade, R.L. Calderon, J.M. Roberts, M.J. Beach , S.L. Roy. Causes of outbreaks associated with drinking water in the United States from 1971 to 2006. Clin. Microbiol. Rev., 23 (2010), pp. 507-528. https://doi.org/10.1128/CMR.00077-09

Crittenden et al., 2012

J.C. Crittenden, R.R. Trussell, D.W. Hand, K.J. Howe, G. Tchobanoglous MWH's Water Treatment: Principles and Design. (third ed.), John Wiley \& Sons, Inc., Hoboken, New Jersey (2012).

Delaire et al., 2015

C. Delaire, C.M. Van Genuchten, K.L. Nelson, S.E. Amrose, A.J. Gadgil. Escherichia coli attenuation by Fe electrocoagulation in synthetic Bengal groundwater: effect of $\mathrm{pH}$ and natural organic matter. Environ. Sci. Technol., 49 (2015), pp. 9945-9953. https://doi.org/10.1021/acs.est.5b01696

DeSimone, 2009

L.A. DeSimone. Quality of Water from Domestic Wells in Principal Aquifers of the United States, 1991-2004. U.S. Geological Survey Scientific Investigations Report 2008-5227 (2009), p. 139. available online at http://pubs.usgs.gov/sir/2008/5227

Drees et al., 2003

K.P. Drees, M. Abbaszadegan, R.M. Maier. Comparative electrochemical inactivation of bacteria and bacteriophage. Water Res., 37 (2003), pp. 2291-2300. https://doi.org/10.1016/S0043-1354(03)00009-5

Dubrawski et al., 2013

K.L. Dubrawski, M. Fauvel, M. Mohseni. Metal type and natural organic matter source for direct filtration electrocoagulation of drinking water. J. Hazard Mater., 244-245 (2013), pp. 135-141. https://doi.org/10.1016/j.jhazmat.2012.11.027

EDR Group, 2013

EDR Group. Failure to Act: the Impact of Current Infrastructure Investment on America's Economic Future. American Society of Civil Engineers (2013).

Fang et al., 2006

Q. Fang, C. Shang, G. Chen. MS2 Inactivation by chloride-assisted electrochemical disinfection. J. Environ. Eng., 132 (2006), pp. 13-22. https://doi.org/10.1061/(ASCE)0733-9372(2006)132:1(13)

Ferrer et al., 2013

O. Ferrer, R. Casas, C. Galvañ, F. Lucena, A. Vega, O. Gibert, J. Jofre, X. Bernat. Challenge tests with virus surrogates: an accurate membrane integrity evaluation system? Desalin. Water Treat., 51 (2013), pp. 4947-4957. https://doi.org/10.1080/19443994.2013.795339

Grabow, 2007

W.O.K. Grabow. Overview of health-related water virology. A. Bosch (Ed.), Human Viruses in Water, Elsevier, Amstersdam (2007), pp. 1-26.

Grabow, 2001

W.O.K. Grabow. Bacteriophages: update on application as models for viruses in water. WaterSA, 27 (2001), pp. 251-268. https://doi.org/10.4314/wsa.v27i2.4999

Haselow et al., 2003 
J.S. Haselow, R.L. Siegrist, M. Crimi, T. Jarosch. Estimating the total oxidant demand for in situ chemical oxidation design. Remediation, 13 (2003), pp. 5-16. https://doi.org/10.1002/rem.10080

$\underline{\text { He et al., } 2019}$

Y. He, H. Lin, Z. Guo, W. Zhang, H. Li, W. Huang. Recent developments and advances in boron-doped diamond electrodes for electrochemical oxidation of organic pollutants. Separ. Purif. Technol., 212 (2019), pp. 802-821. https://doi.org/10.1016/j.seppur.2018.11.056

Heffron and Mayer, 2016

J. Heffron, B.K. Mayer. Virus mitigation by coagulation: recent discoveries and future directions. Environ. Sci. Water Res. Technol., 2 (2016), pp. 443-459. https://doi.org/10.1039/C6EW00060F

Heffron et al., 2019a

J. Heffron, B. McDermid, E. Maher, P. McNamara, B.K. Mayer. Mechanisms of virus mitigation and suitability of bacteriophages as surrogates in drinking water treatment by iron electrocoagulation. Water Res. In Rev. (2019)

Heffron et al., 2019b

J. Heffron, B. McDermid, B.K. Mayer. Bacteriophage inactivation as a function of ferrous iron oxidation. Environ. Sci. Water Res. Technol. (2019). (in press). https://doi.org/10.1039/c9ew00190e

Huang et al., 2016

X. Huang, Y. Qu, C.A. Cid, C. Finke, M.R. Hoffmann, K. Lim, S.C. Jiang. Electrochemical disinfection of toilet wastewater using wastewater electrolysis cell. Water Res., 92 (2016), pp. 164-172. https://doi.org/10.1016/j.watres.2016.01.040

Hussain et al., 2014

S.N. Hussain, N. de las Heras, H.M.A. Asghar, N.W. Brown, E.P.L. Roberts. Disinfection of water by adsorption combined with electrochemical treatment. Water Res., 54 (2014), pp. 170-178.

https://doi.org/10.1016/j.watres.2014.01.043

Jeong et al., 2006

J. Jeong, J.Y. Kim, J. Yoon. The role of reactive oxygen species in the electrochemical inactivation of microorganisms. Environ. Sci. Technol., 40 (2006), pp. 6117-6122. https://doi.org/10.1021/es0604313

$\underline{\text { Kim et al., } 2011}$

J.Y. Kim, C. Lee, D.C. Love, D.L. Sedlak, J. Yoon, K.L. Nelson. Inactivation of MS2 coliphage by ferrous ion and zero-valent iron nanoparticles. Environ. Sci. Technol., 45 (2011), pp. 6978-6984. https://doi.org/10.1021/es201345y

Lacasa et al., 2013

E. Lacasa, E. Tsolaki, Z. Sbokou, M.A. Rodrigo, D. Mantzavinos, E. Diamadopoulos. Electrochemical disinfection of simulated ballast water on conductive diamond electrodes. Chem. Eng. J., 223 (2013), pp. 516-523. https://doi.org/10.1016/i.cej.2013.03.003

Lakshmanan and Clifford, 2009

D. Lakshmanan, D.A. Clifford. Ferrous and ferric ion generation during iron electrocoagulation. Environ. Sci. Technol., 43 (2009), pp. 3853-3859.

Legube and Karpel Vel Leitner, 1999

B. Legube, N. Karpel Vel Leitner. Catalytic ozonation: a promising advanced oxidation technology for water treatment. Catal. Today, 53 (1999), pp. 61-72. https://doi.org/10.1016/S0920-5861(99)00103-0

Li et al., 2012

L. Li, C.M. van Genuchten, S.E.A. Addy, J. Yao, N. Gao, A.J. Gadgil. Modeling As(III) oxidation and removal with iron electrocoagulation in groundwater. Environ. Sci. Technol., 46 (2012), pp. 12038-12045. https://doi.org/10.1021/es302456b

Litter et al., 2018 
M. Litter, K. Bircher, T. Oppenländer, J. Bolton, O. Keen. Standard reporting of electrical energy per order (EEO) for UV/H2O2 reactors (IUPAC Technical Report). Pure Appl. Chem., 90 (2018), pp. 1487-1499. https://doi.org/10.1515/pac-2017-0603

Llanos et al., 2014

J. Llanos, S. Cotillas, P. Cañizares, M.A. Rodrigo. Effect of bipolar electrode material on the reclamation of urban wastewater by an integrated electrodisinfection/electrocoagulation process. Water Res., 53 (2014), pp. 329-338. https://doi.org/10.1016/j.watres.2014.01.041

Macpherson, 2015

J.V. Macpherson. A practical guide to using boron doped diamond in electrochemical research. Phys. Chem. Chem. Phys., 17 (2015), pp. 2935-2949. https://doi.org/10.1039/c4cp04022h

Mascia et al., 2013

M. Mascia, A. Vacca, S. Palmas. Electrochemical treatment as a pre-oxidative step for algae removal using Chlorella vulgaris as a model organism and BDD anodes. Chem. Eng. J., 219 (2013), pp. 512-519. https://doi.org/10.1016/j.cej.2012.12.097

Mayer et al., 2008

B.K. Mayer, H. Ryu, M. Abbaszadegan. Treatability of U.S. Environmental Protection Agency contaminant candidate list viruses: removal of coxsackievirus and echovirus using enhanced coagulation. Environ. Sci. Technol., 42 (2008), pp. 6890-6896. https://doi.org/10.1021/es801481s

Palmas et al., 2007

S. Palmas, A.M. Polcaro, A. Vacca, M. Mascia, F. Ferrara. Influence of the operating conditions on the electrochemical disinfection process of natural waters at BDD electrodes. J. Appl. Electrochem., 37 (2007), pp. 1357-1365. https://doi.org/10.1007/s10800-007-9368-3

Polcaro et al., 2009

A.M. Polcaro, A. Vacca, M. Mascia, S. Palmas, J. Rodiguez Ruiz. Electrochemical treatment of waters with BDD anodes: kinetics of the reactions involving chlorides. J. Appl. Electrochem., 39 (2009), pp. 2083-2092. https://doi.org/10.1007/s10800-009-9870-x

Powder Technology Inc., 2016

Powder Technology Inc. Safety Data Sheet: Arizona Test Dust. (2016)

R Core Team, 2014

R Core Team R: A Language and Environment for Statistical Computing. (2014)

Radjenovic and Sedlak, 2015

J. Radjenovic, D.L. Sedlak. Challenges and opportunities for electrochemical processes as next-generation technologies for the treatment of contaminated water. Environ. Sci. Technol., 49 (2015), pp. 1129211302. https://doi.org/10.1021/acs.est.5b02414

$\underline{\text { Rajab et al., } 2015}$

M. Rajab, C. Heim, T. Letzel, J.E. Drewes, B. Helmreich. Electrochemical disinfection using boron-doped diamond electrode - the synergetic effects of in situ ozone and free chlorine generation. Chemosphere, 121 (2015), pp. 47-53. https://doi.org/10.1016/j.chemosphere.2014.10.075

Reed and Muench, 1938

L.J. Reed, H. Muench. A simple method of estimating fifty per cent endpoints. Am. J. Hyg., 27 (1938), pp. 493497. https://doi.org/10.1093/OXFORDJOURNALS.AJE.A118408

Saha and Gupta, 2017

J. Saha, S.K. Gupta. A novel electro-chlorinator using low cost graphite electrode for drinking water disinfection. Ionics (Kiel)., 23 (2017), pp. 1903-1913.

Sakamoto et al., 1986

Y. Sakamoto, M. Ishiguro, G. Kitagawa. Akaike Information Criterion Statistics. Springer, Netherlands (1986)

Sjogren and Sierka, 1994 
J.C. Sjogren, R.A. Sierka. Inactivation of phage MS2 by iron-aided titanium dioxide photocatalysis. Appl. Environ. Microbiol., 60 (1994), pp. 344-347.

Sreethawong and Chavadej, 2008

T. Sreethawong, S. Chavadej. Color removal of distillery wastewater by ozonation in the absence and presence of immobilized iron oxide catalyst. J. Hazard Mater., 155 (2008), pp. 486-493.

https://doi.org/10.1016/j.jhazmat.2007.11.091

Stumm and Lee, 1961

W. Stumm, F.G. Lee. Oxygenation of ferrous iron. Ind. Eng. Chem., 53 (1961), pp. 143-146. https://doi.org/10.1021/ie50614a030

Tai et al., 2004

C. Tai, J.F. Peng, J.F. Liu, G. Bin Jiang, H. Zou. Determination of hydroxyl radicals in advanced oxidation processes with dimethyl sulfoxide trapping and liquid chromatography. Anal. Chim. Acta, 527 (2004), pp. 73-80. https://doi.org/10.1016/i.aca.2004.08.019

Tanneru and Chellam, 2012

C.T. Tanneru, S. Chellam. Mechanisms of virus control during iron electrocoagulation--microfiltration of surface water. Water Res., 46 (2012), pp. 2111-2120. https://doi.org/10.1016/i.watres.2012.01.032

Tanneru et al., 2014

C.T. Tanneru, N. Jothikumar, V.R. Hill, S. Chellam. Relative insignificance of virus inactivation during aluminum electrocoagulation of saline waters. Environ. Sci. Technol., 48 (2014), pp. 14590-14598. https://doi.org/10.1021/es504381f

Vepsäläinen et al., 2009

M. Vepsäläinen, M. Ghiasvand, J. Selin, J. Pienimaa, E. Repo, M. Pulliainen, M. Sillanpää. Investigations of the effects of temperature and initial sample $\mathrm{pH}$ on natural organic matter (NOM) removal with electrocoagulation using response surface method (RSM). Separ. Purif. Technol., 69 (2009), pp. 255-261. https://doi.org/10.1016/i.seppur.2009.08.001

Washington Administrative Code, 2017

Washington Administrative Code. WAC 246-290-451, Disinfection of Drinking Water. Washington Administrative Code (2017)

Westerhoff et al., 2007

P. Westerhoff, S.P. Mezyk, W.J. Cooper, D. Minakata. Electron pulse radiolysis determination of hydroxyl radical rate constants with Suwannee river fulvic acid and other dissolved organic matter isolates. Environ. Sci. Technol., 41 (2007), pp. 4640-4646. https://doi.org/10.1021/es062529n

World Health Organization, 1996

World Health Organization. Guidelines for Drinking-Water Quality: Health Criteria and Other Supporting Information. (second ed.), World Health Organization, Geneva (1996)

Zhu et al., 2005

B. Zhu, D.A. Clifford, S. Chellam. Virus removal by iron coagulation-microfiltration. Water Res., 39 (2005), pp. 5153-5161. https://doi.org/10.1016/j.watres.2005.09.035 